\title{
Słowiańskie nazwy 'źrenicy' w świetle materiałów gwarowych i źródeł historycznych
}

Nazwy ‘źrenicy’ w gwarach słowiańskich są szczególnie liczne. W materiałach OLA jest ich ponad 150. Niektóre tworzą rozległe areały, jednak przeważnie o nieostrych granicach. Często są przemieszane, a w wielu punktach występuje nawet obocznie po kilka nazw. Niektóre z nich są poświadczone tylko w jednym punkcie i stanowią rzeczywiście doraźne innowacje, wiele ma jednak potwierdzenia w materiałach spoza OLA, świadczące o ich powszechnej znajomości na pewnym terenie.

Bardzo skomplikowane zróżnicowanie geograficzne nazw ‘źrenicy’ przedstawiam na dwóch mapach, pomysłowo opracowanych przez Panią Profesor Dorotę Rembiszewską. Pierwsza (onomazjologiczna) stanowi modyfikację mapy punktowej w OLA, na której - dla uwyraźnienia podziałów geograficznych - kilka szerzej rozpowszechnionych i tworzących bardziej zwarte areały nazw przedstawiono za pomocą płaszczyzn, a ponadto wprowadzono dwie izoleksy wyznaczające maksymalne zasięgi określonych leksemów. Na mapie drugiej (motywacyjnej) pokazano za pomocą zróżnicowanych płaszczyzn następujące grupy motywacyjne:

I. Nazwy motywowane przez czasowniki o znaczeniu 'patrzeć'. Jest to grupa najliczniejsza. Podstawę tworzą czasowniki ${ }^{*} z$ brěti, ${ }^{*}$ ględati, ${ }^{\star}$ patriti, ${ }^{\star}$ vidèti, a także ${ }^{\star} z e ̌ t i$. Derywaty od ${ }^{*} z$ brětti (i innych postaci apofonicznych 
tego rdzenia) i od * ględati są liczne i trudno nieraz oddzielić osobne postaci morfologiczne od ich wariantów fonetycznych.

II. Nazwy motywowane przez wyrazy oznaczające obraz odbijający się w źrenicy. Podstawę stanowią wyrazy oznaczające 'małego człowieka', 'dziewczynkę,' 'lalkęe' (zabawkę) itp. Do tej grupy motywacyjnej należy też kilka nazw zapożyczonych.

III. Nazwy motywowane czarnym kolorem 'źrenicy'.

IV. Nazwy motywowane przez wyrazy oznaczające niewielkie przedmioty kuliste, świecące i błyszczące.

V. Zdrobniałe nazwy oka.

Jak zwrócono uwagę już dawniej (por. Kopečný 1960, 185-192, z dalszą literaturą), grupy nazw 'źrenicy' o podobnej motywacji semantycznej nie są ograniczone tylko do języków słowiańskich, lecz właściwe są również innym językom indoeuropejskim i nieindoeuropejskim. Nawiązania pozasłowiańskie, mogące stanowić przedmiot osobnego opracowania, w tym artykule pomijam.

Przy omawianiu nazw według przedstawionego schematu uwzględniam materiały porównawcze $\mathrm{z}$ wcześniejszych opracowań gwarowych i słowników historycznych, co pozwala na uchwycenie pewnych zmian słownictwa dotyczącego 'źrenicy' w językach słowiańskich.

\section{Nazwy motywowane przez czasowniki o znaczeniu 'patrzeć'}

A. Nazwy od rdzenia ${ }^{\star} z b r-/{ }^{*} z o r-$

Od postaci ${ }^{\star} z o r-$ pochodzi kilka derywatów. Formę ${ }^{\star}$ zorz określającą 'źrenicę' zanotowano w OLA w jednym punkcie ukraińskim jako zir (419). $\mathrm{W}$ innych źródłach brak potwierdzenia tej nazwy. Słownik ukraiński podaje natomiast зip, gen. зópy w znaczeniach 'zmysł wzroku', 'spojrzenie', 'oczy' (SUM III 576).

Formę *zorkz 'źrenica' zanotowano w kilku niewielkich wysepkach: w Macedonii zrak (98), na Białorusi $z a^{\prime}$ rok (378), na północy Rosji w pobliżu jeziora Onega $z o^{\prime} r o k(553,567,589)$ i w południowej Rosji $z a^{\prime} r o k(823$, $830-832,848)$. W innych źródłach potwierdzenia dla formy macedońskiej i białoruskiej nie znalazłem. Natomiast gwarowy słownik rosyjski wskazuje na szerszy zasięg tej nazwy, poświadcza bowiem зорóк, pl зоркú w znaczeniu 'źrenica' z północy Rosji oraz m.in. spod Pskowa i Tweru. Formę зópкu 'źrenica' notował też rosyjski słownik akademicki z 1907 roku (SRNG XI 341, 343). Potwierdzenie ma również zanotowana w OLA postać fonetyczna z miękką spółgłoską $r^{\prime}-z o^{\prime} r^{\prime} o k$ (w p. 567 i 568 na północy Rosji), por. зopëк w SRNG XI 
338. Sporadycznie зорóк 'źrenica' znana była także na terenie Ukrainy, ESUM II 279 s.v. зpímu i II 281 s.v. зpoк określa ją jako dialektalną. Występująca w ję-

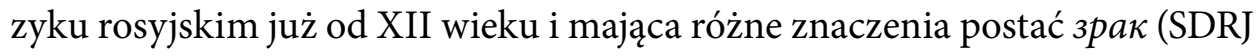
III 403-404, SRJ XI-XVII, t. VI 62-63) była sporadycznie odnotowana w znaczeniu 'źrenica' dopiero w 2. połowie XVII wieku (SRJ XI-XVII l.c.) i w 1731 roku (SRJ XVIII, t. VIII 228). Postać зрак w znaczeniu 'źrenica' pojawia się również w zabytku ukraińskim z 1642 roku (SUM XVI-XVII, t. XII 177). Nazwę spak 'źrenica' notuje też Dzendzeliwski III (1993) m. 301 na Ukrainie Zakarpackiej w dwóch punktach koło Użhorodu i koło m. Chust w środkowej części Zakarpacia.

Natomiast znana w języku białoruskim i ukraińskim postać fonetyczna зрок, mająca znaczenie 'wzrok', uważana jest za zapożyczenie polskiego wyrazu wzrok (ESBM III 345, ESUM II 281, SUM XVI-XVII, t. XII 188 z XVII wieku).

Bardzo szeroki zasięg w gwarach ma forma ${ }^{*} z / /$ orčbkr $(/ />d)$. Występuje dosyć powszechnie w całej Rosji i we wschodnich częściach Białorusi i Ukrainy. Jej względnie zwarty zachodni zasięg na terenie Białorusi i Ukrainy wyznacza izoleksa $\mathrm{nr}$ 2. W Rosji, zwłaszcza zaś na południe od Moskwy, występuje - nieraz obocznie - wiele innych nazw. Nazwa ${ }^{\star} z / /$ orčbkr została też zapisana w kilku rozproszonych punktach na zachód od tak wyznaczonej izoleksy, a mianowicie w punktach $336,361,382,416,470,472$. Na znacznym obszarze środkowej i wschodniej Ukrainy spotyka się obocznie nazwę *čelověčbkr (por. niżej). Tereny te tworzą szeroki pas przejściowy z obiema nazwami, a nawet $\mathrm{z}$ wyspą wyłącznego występowania nazwy ${ }^{\star}$ čelověč bk północnym wschodzie Ukrainy w punktach 442, 444, 463, 479, 480. Maksymalny jej stosunkowo zwarty wschodni zasięg pokazuje jednolita szara płaszczyzna. Sporadycznie zanotowano *̌́elověč bk także na wschód od tej płaszczyzny w punktach: $367,392,521,836,849$.

Dosyć powszechnie notowano ${ }^{\star} z o r c ̌ b k r b$ w fonetycznie cerkiewnej (Vasmer ESRJ II 105) postaci zra'čok. Sporadycznie odnotowano postać z pełnogłosem zoro'̌́ok $(578,723)$, a także postaci z grupą -ro-: na Białorusi $z$ dročcok (389) i zro'čok (394), na Ukrainie $z d r o$ čok $(418,425)$ i w Rosji zro'čok $(638,639,701)$, sro'čok (745). Form z -ro- ze względu na geografię chyba nie należy tłumaczyć wpływem polskim, lecz raczej rodzimą redukcją pierwszej sylaby nieakcentowanej. Atlas białoruski ma na ogół formy zgodne z OLA, jednakże naszemu zapisowi $z d r a{ }^{\prime} c ̌ k$ w punkcie $391 \mathrm{w}$ LAB III m. 46, s. 38 odpowiada forma здрочо́к (tam punkt 55A). Gwarowy słownik rosyjski, ze względu na swój dyferencyjny charakter, rosyjskiej formy ogólnej зрачóк 'źrenica' w ogóle nie notuje. Brak w nim też postaci z grupą -ro-, natomiast podaje formy $\mathrm{z}$ pełnogłosem зорочóк z powołaniem się na słowniki akademickie z 1847 i 1907 roku 
oraz na materiał z części azjatyckiej Rosji spod Omska, a także зоро́чек spod Tomska. Dal I 694 przytoczył nazwę зорочéк 'źrenica', traktując ją jako południoworosyjską. Forma ogólna зрачóк 'źrenica' pojawia się w języku rosyjskim późno, mianowicie dopiero pod koniec XVIII wieku (SRJ XVIII, t. VIII 228), natomiast jej podstawa зрак w znaczeniu 'źrenica' znana była już wcześniej (por. wyżej). Później зрачóк się upowszechnia, por. SSRLJ II 1336-1337. Wcześniej poświadczona jest forma $\mathrm{z}$ pełnogłosem зорочéк - w słowniku Polikarpowa (1704) i w przekładzie z 1746 roku (SRJ XVIII l.c.)

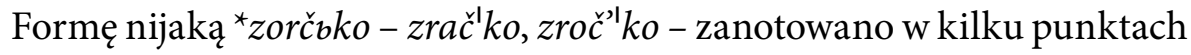
na północy Rosji koło Wołogdy, Jarosławia i Iwanowa $(642,643,665,724)$ i dalej na północ (578). Ich potwierdzenia w innych źródłach nie znalazłem. Oczekiwanej formy z pełnogłosem nie odnotowano. Może należy tu zaliczyć też zapisaną na Białorusi formę zrač́ ko (328) - tak samo w tym samym punkcie (зрачкó) w LAB III m. 46, s. 38, choć można tu przyjąć formę wyjściową ${ }^{*} z$ zrěč $k$ ko (por. niżej).

Zupełnie sporadycznie w znaczeniu 'źrenica' zanotowano w OLA formację *zorbnica, częściej natomiast formalnie zdrobniałą postać ${ }^{\star} z o r b n i c ̌ b k a$. Nazwy te w niektórych językach słowiańskich występują częściej w znaczeniu 'gwiazda poranna, jutrzenka', czego tu bliżej nie omawiam.

Formę $z$ zorbnica 'źrenica' zapisano dwukrotnie na Ukrainie: zir'nyc'a (429) i $z^{\prime} i^{\prime} n y c^{\prime} a$ (513), formalnie deminutywną formę * zorbničska w dosyć zwartym areale punktów słowackich, z którymi łączy się polski punkt 325 i morawski 202 (zupełnie odosobniony jest natomiast punkt $178 \mathrm{w}$ zachodnich Czechach). Nazwy te znajdują potwierdzenie w materiałach spoza Atlasu, głównie ze Słowacji. Wyrazy zornica i zornička jako nieco przestarzałe nazwy 'źrenicy' notuje słownik języka słowackiego (SSJ V 687). Wielokrotnie zornice i zornička w znaczeniu 'źrenica' odnotowują też słowniki czeskie (Jg V 736, Kott V 607, VII 1152, PS VIII 702-703, SSJČ IV 816). Nieraz określają je jako słowackie lub śląskie, przytaczają jednak dosyć liczne poświadczenia z literatury czeskiej. Basara 1975, 82 podaje nazwę zorńica 'źrenica' z Pietrzwałdu na Śląsku Cieszyńskim, a Sobierajski (III, 1973, m. 228, s. 25, 26) zornica i kilkakrotnie zorniczka z gwar polskich na Spiszu.

Zupełnie odosobniona jest, zanotowana we wschodniej Słowacji (225), zora:yka - ${ }^{\star} z o r-(j)-a n-\imath k-a$.

W gwarach rosyjskich sporadyczne i rozproszone są takie nazwy 'źrenicy', jak na północy *ozorkz - ozo'rok (534), ozo'rok, uzo'rok (588), na południu ${ }^{*}$ ozorčzkz - azra'čok (821) i na północny wschód od Moskwy koło Kostromy ${ }^{*}$ ozorčbko - ozoročl $k o$ (707). Dwie pierwsze mają zresztą potwierdzenie w słowniku Dala II 660 озоро́к, озоро́чек bez podania lokalizacji (por. też SRNG 
XXIII 100). Postać озорочок poświadczona jest ponadto z 2. połowy XVIII wieku, zapewne w znaczeniu 'rogówka oka' (SRJ XVIII, t. VIII 228, s.v. зрачóк).

Utworzone od postaci rdzenia *zbr- 'patrzeć' nazwy 'źrenicy' w OLA są szczególnie liczne. Trudno tu nieraz wyraźnie rozgraniczyć poszczególne formy, stąd konieczność przytaczania wielu - budzących nieraz wątpliwości interpretacyjne - zapisów terenowych. Przedstawię je, uwzględniając podobieństwo formacji i ich frekwencję. Zacznę jednak od postaci stanowiących pewną analogię do przedstawionych wyżej z przedrostkiem $o$-. Jest to występujący w kilku punktach na południe od Moskwy ${ }^{\star} o z b r ø k r-a z^{\prime} a^{\prime} r o k$ (751), az'érok (763), az'ilrok (765) i az'a'rok (768) oraz formalnie deminutywny ${ }^{\star}$ ozbrøčcb - az'a'roč̉ te wyrazy ze słowem озеро 'jezioro'. Formę озеро́к 'źrenica' Vasmer ESRJ III 125 podawał znad dalekiej Kołymy, a SRNG XXIII 92 ponadto spod Kaługi. Na północy guberni wołogodzkiej zanotowano w OLA formę rodzaju nijakiego ${ }^{*}$ ozbrøko - oz'er'ko (590), o'zerko, ozer'ko (591), oz'er'ko (625), oz'or'ko (626). Ma ona również potwierdzenie w rosyjskim słowniku gwarowym spod Nowogrodu i z części azjatyckiej Rosji (SRNG XXIII 91). Zupełnie odosobniony jest natomiast zanotowany na samej północy Rosji ${ }^{\star}$ ozbrenyšb - oz'e' r'onbı̌ (545).

Postać ${ }^{\star} Z / / b r z k z(Z>s, / />v)$ zajmuje dosyć rozległy, choć bardzo nieregularny obszar od Tweru i Smoleńska, przez zachodnie okolice Moskwy, po tereny koło Kaługi, Tuły, Riazania, Briańska i Orła, a sporadycznie pojawia się też pod Woroneżem (834) i Biełgorodem (844). Fonetycznie najczęściej zapisywano $z^{\prime} a^{\prime}$ rok, sporadycznie zaś z'e rok (815), že rok (803), s'a'rok (799), sv'a'rok (792) i z'v'a'rok $(805,809)$. Podobny zasięg ma nazwa зерóк 'źrenica' w gwarowym słowniku rosyjskim (SRNG XI 269). Sporadycznie odnotowano także formalnie deminutywny ${ }^{\star} z b r z c ̌ c b k z-z^{\prime} a^{\prime}$ roč $i k$ spod Tuły (804) i Briańska $(813,814)$, którą SRNG 1.c. podaje spod Smoleńska (зеро́чeк). Postać ${ }^{\star} z$ brъkъ - z'a'rok występuje też na Białorusi: koło Mińska $(358,368)$. Z tych samych punktów podaje зярóк również Atlas białoruski (LAB III m. 42, s. 38).

Osobno potraktowana postać ${ }^{\star} z / / i r z k z(/ />v)-z^{\prime} i^{\prime} r o k$, sporadycznie $z^{\prime \prime} v^{\prime}$ irok (447), występuje na samej północy Ukrainy $(446,447)$ i w Rosji w rozproszeniu koło Smoleńska (729, 749, 760), Kaługi (776), Tuły (777) i Riazania (807). Formę зирóк jako osobną notował już Dal I 694, a gwarowy słownik rosyjski podaje ją spod Orła, Kurska i Kaługi (SRNG XI 284). W grę może wchodzić tu także wariant formy poprzedniej, tj. ${ }^{\star} z / /$ rrøkb.

Nazwę ${ }^{*} z / /$ brěnica $(/ />d)$ zanotowano w OLA głównie z terenu Polski, przede wszystkim z jej części południowej i wschodniej - z Małopolski, Mazowsza i Podlasia, sporadycznie jednak też ze Śląska (291, 308), Wielkopolski $(259,269)$, Kaszub (241) i spod Tucholi (250), również w punkcie przesiedleń- 
czym pod Gorzowem Wielkopolskim (247). Nazwa ta wykazuje wielką różnorodność form fonetycznych: źreńica, zreńica, źryńica, źžeńica, źrańica, źraníica, $z$ dṛ̌níica - u Sychty V $206 z$ d'řeńica właśnie spod Pucka, ždžyńica (269) itp., por. dalsze warianty w MAGP I s. 121 i w AGM VIII s. 87. W materiałach spoza OLA poświadczona jest również morfologicznie nieco odmienna ${ }^{\star} z / /$ brelbnica $(/ />d)$. MAGP I 42, s. 120 odnotowuje formę źrelńica z gwary polskiej spod Starej Lubowni na Spiszu, a Sychta VI 205 zdř̀ élnica sporadycznie spod Pucka.

Poza tym ${ }^{\star} z$ brěnica, częściej forma deminutywna ${ }^{\star} z$ zrěničck $a$, została zapisana w zachodniej Słowacji, w zachodniej części Słowacji środkowej i w punkcie słowackim na terenie Węgier. Dosyć często występują one obocznie $\mathrm{z}$ innymi nazwami. Zupełnie odosobniony jest zapis $z^{\prime} r^{\prime} e n b l c ̌ k a \mathrm{w}$ punkcie rosyjskim 710 . Materiały z licznych opracowań z gęstszą siatką punktów pokazują, że zasięg tych nazw jest, lub może był w przeszłości, znacznie szerszy zarówno w gwarach, jak i w językach ogólnych. W MAGP I 42, s. 121 nazwa źrenica zajmuje trzy niewielkie wyspy: w Małopolsce, w części Wielkopolski i w okolicy Puław, ale sporadyczne przykłady notowano też w okolicy Sieradza, Łaska i Piotrkowa, w punkcie słowińskim (z LSW zdřlieńica), koło Ostrowi Mazowieckiej i w całym wschodnim pasie pogranicznym. Opracowania dysponujące gęstszą siatką punktów pokazują, że w różnym nasileniu *zbrěnica występuje właściwie w całej Polsce: w AJK IV 151, s. 36 rzadko na północy i na południu Kaszub, częściej natomiast w dialektach pozakaszubskich badanego obszaru, w rozproszeniu, często obocznie z innymi nazwami, na całym Mazowszu (AGM VIII 382, s. 87-88), w Wielkopolsce (z prac Tomaszewskiego), powszechnie na Lubelszczyźnie (Pelcowa SłLub), na Kielecczyźnie, głównie południowej (Dejna AtlKiel VI 796), sporadycznie na Śląsku (Zaręba AJŚ IV 615), na Śląsku Cieszyńskim po obu stronach granicy państwowej koło Cieszyna i Trzyńca (Basara 1975: m. 127, a także u Kellnera VLN 332), w gwarach polskich na Spiszu źrenica i źreniczka (Sobierajski III, 1973, m. 228, s. 25-26). Dalsze szczegółowe lokalizacje podaje AGM VIII l.c. W języku polskim źrenica, źrzenica poświadczona jest od XV wieku (SStp XI 536).

Na Słowacji formy te odnotowane są nieco później, ale poświadczone są wszystkie trzy: zrelnica pojawia się w 1666 i 1706-1707 roku, a zrenica i zrenička w XVIII wieku, pierwsza w czterech, a druga w dwóch dokumentach. Zrenica i zrenička notuje też współczesny słownik słowacki (SSJ V 712). Odpowiedni tom słownika gwarowego $\mathrm{z}$ tymi wyrazami jeszcze się nie ukazał.

Z języka czeskiego znane jest dawne poświadczenie formy ${ }^{\star} z / /$ brělbnica (// $>$ d) - zřriedlnicě z Deut 32, 10 w Biblii drezdeńskiej i ołomunieckiej (z 1417 r.). Kott V 656-657 podaje žrenice, powołując się na encyklopedię i słownik, ale dalsze cytaty pochodzą ze źródeł językowo słowackich i mają słowacką po- 
stać zrenica. Jak się zdaje, źrenica ograniczona jest do Śląska Cieszyńskiego (por. wspomniane już wyżej prace Basary i Kellnera).

Poza tym dosyć częste są zapisy nazwy ${ }^{\star} z$ brěnica w dawnych zabytkach białoruskich i ukraińskich: HSBM XIII 187 odnotowuje зреница 'źrenica' 8 razy z XVI-XVII wieku, a SUM XVI-XVII, t. XII 180 зрьниця, зрьница, зреница, зрениия z XVII wieku w znaczeniach 'źrenica' (4 razy) i 'oko' (3 razy). Poświadczenia biblijne, a zwłaszcza w zwrocie „сохранити... яко зренииу ока", nasuwa przypuszczenie, że może tu wchodzić w grę wpływ

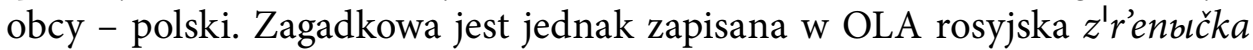
(710), której potwierdzenia w źródłach rosyjskich spoza naszego Atlasu jednak nie znalazłem.

Derywat ${ }^{\star} z / /$ rěn -zachodniej Białorusi ( $z^{\prime}$ renka, też $\left.z^{\prime} r^{\prime} e n k a\right)$, poza tym z punktu ukraińskiego we wschodniej Słowacji $z^{\prime} r e n ' k a$ (233) i z Ukrainy Zakarpackiej spod Użhorodu $z d^{\prime}$ riøka (465). Ponadto zapisano $\mathrm{w}$ dwóch punktach w Witebskiem *zbrěnačbka $(328,334)$. Porównanie materiałów OLA z Atlasem białoruskim pokazuje, że w materiałach białoruskich dla OLA dokonano pewnego uproszczenia. $\mathrm{W}$ dwóch punktach na wschodzie Białorusi podano zapis $z^{\prime} r^{\prime} e n k a(379,381)$, podczas gdy w materiałach LAB III s. 38 z tych punktów zapisano зре́нко (jednak w LAB III na mapie 46 wszystkie te formy oddano jednym znakiem). Dla OLA trzeba więc przyjąć trzy formy: ${ }^{*} z$ brěnøka, ${ }^{*} z$ zrěnzko i ${ }^{*} z$ brěnačıka. Dwie pierwsze mają potwierdzenie w materiałach spoza OLA. Forma żeńska zъrěnzka jest dziś białoruską nazwą literacką 'źrenicy', por. зрэнка w TSBM II 516 i w ESBM III 347, a gwarowa зронкá występuje w pobliżu granicy z Rosją i Łotwą (SłPogr II 326). Poza tym znana jest ukraińska здрінка і зрінка z Łemkowszczyzny (Hrinč II 147, 184 i ESUM II 279 s.v. зрímu), a dokładniejszy jej zasięg pod Użhorodem wyznacza Dzendzeliwski III (1993) na m. 301, podając z tych stron formy здрінка, зрінка і три́нка. Wreszcie znana jest polska gwarowa $z d^{\prime}$ renka z Serpelic koło Białej Podlaskiej (MAGP I 42, s. 120), przejęta zapewne z ukraińskiego. Forma rodzaju nijakiego ${ }^{\star} z$ zrěn u Hrinč II 18 i w ESBM l.c.) oraz dialektalne zreøko ze słowackiej wsi Plavnica koło Starej Lubowni na Spiszu (por. Sobierajski III, 1973, s. 26). ESUM 1.c. podaje ponadto, też zapewne łemkowską, formę зрівка ( ${ }^{\star} z$ zrěvъka). Sobierajski notuje ponadto osobliwą formę žorofka $\left({ }^{*}\right.$ zbrovøka / ${ }^{\star}$ zerovøka), utworzoną od częstotliwej formy czasownika zierać, ziarać, ziorać 'patrzeć'.

Derywat ${ }^{*} z$ brětelınica, określany nieraz jako literacki, został zapisany w OLA w 7 rozproszonych punktach czeskich (zři:telnice, žretelnice itp.), poza tym raz zanotowano postać formalnie deminutywną ${ }^{*} z$ zrětelbničbka 
- zretelńička w słowackim punkcie 208. Nazwę zřetelńica 'źrenica' z Sobieszowic na Śląsku Cieszyńskim podaje też Basara 1975, 28, a Machek ES-2, 718 zřetelnička z południowych Czech. W języku czeskim nazwa ta jest poświadczona od dawna, zwłaszcza w biblijnych (Psałterz, Stary Testament) zwrotach typu „ostřiehati / opatrovati koho jako zřetelnici oka svého" 'strzec kogo pilnie'. Dawniej w języku czeskim występowała postać zřrietedlnice, zřetedlnice (MSČS 673, Jg V 771), później wstawne $d$ zanikło i pojawiły się postaci zř́telnice, žretelnice (Kott V 660, PS VIII 836), deminutivum zř́telnička. Dziś zř́telnice 'źrenica' uważana jest za wyraz książkowy. Nazwa ta występowała też w dawnym języku słowackim. HSSJ VII 391-392 notuje ją w postaciach zretelnica, zretedlnička, zretel'nička, zwłaszcza w zwrotach „zachovat', opatrovat', ostrihat' koho ako zretedlnicu / zrete(d)lničku oka svojho". Ze względu na książkowy (biblijny) charakter tych poświadczeń i ich postać fonetyczną z wstawnym $d$ należy tu przyjąć pożyczkę czeską. Dziś SSJ już nazwy tej nie notuje.

W języku staroczeskim w zabytkach sięgających XIV wieku (Svatovitský rukopis, Biblia drezdeńska) występowała również postać zrziedlnice ( ${ }^{*}$ zbrěl/lni$c a ; / />d$ ), znana co najmniej do XVI wieku (Słownik Vodňanskiego), por. MSČS 673, Jg V 771, Kott V 659. Niezależnie pojawia się ona na Spiszu we wsi Kacze koło Starej Lubowni - źrelnica (MAGP I 42, s. 120 z AJPP) i na Kaszubach pod Puckiem - zdř̀ élńica (Sychta VI 205).

Kilka zapisów można chyba uogólnić jako ${ }^{*} z / /$ brěčck $z d r y^{\prime} c^{\prime} \circ k, z d r^{\prime} i^{\prime c} c^{\prime} o k$ (486) i ros. $z^{\prime} r^{\prime} e^{\prime} c^{\prime} \circ k$ koło Wołogdy (668) oraz zr'a'čok spod Tambowa (820). Dla ostatniego zapisu może jednak trzeba przyjąć pierwotną formę ${ }^{\star} z$ brjačık $z$ lub - jak proponuje Žanna Varbot $-{ }^{\star} z b r e ̨ t j b k z$. Potwierdzenia dla tej formacji w innych źródłach nie znalazłem.

Dla trzech zapisów można przyjąć wspólne źródło ${ }^{\star} z / /$ brěčbko $(/ />d)$ : ukr. $z r^{\prime} i c^{\prime} k o$ pod Czerniowcami (496), $z d r^{\prime} a c^{\prime} k o$ na terenie Rumunii (171) i ros. $z r^{\prime} a c^{\prime \prime} k o$ pod Jarosławiem (720). Dwa ostatnie może jednak wywodzą się z pierwotnego ${ }^{\star} z$ zrjačıko lub - jak proponuje Žanna Varbot - ${ }^{\star} z$ zrętjoko. Do formy rosyjskiej nawiązuje zapis зрачкó spod Witebska w Atlasie białoruskim (LAB III m. 46, s. 38).

Postać ${ }^{\star} z / /$ brjačbka lub - jak proponuje Varbot - ${ }^{\star} z / /$ rętjoka $(/ />d)$, zapisaną na Ukrainie Zakarpackiej ( $z^{\prime} r^{\prime} a c^{\prime} k a-466, z^{\prime} r^{\prime} a c ̌ k a, z d^{\prime} r^{\prime} a c ̌ k a-467$, $\left.z^{\prime} r^{\prime} a c^{\prime} k a-483\right)$ i pod Stanisławowem ( $\left.z d^{\prime} r^{\prime} c^{\prime}{ }^{\prime} k a-486\right)$, dokładniej lokalizuje na tych terenach Dzendzeliwski III (1993) m. 301, przytaczając zapisy зp’áıкa i częściej здр’áчка. Formę зря́чка poświadcza również ESUM II 279 ze słownika Żelechowskiego, 1886.

Potwierdzenie w rosyjskim słowniku gwarowym mają sporadycznie zapi-

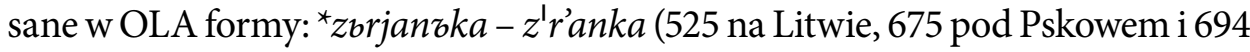


pod Twerem) - зря́нка w SRNG XI 351 spod Pskowa; ${ }^{*} z$ brjanъčъka - z'r’anəčka (525 na Litwie) - зря́ночка w SRNG XI 351 z terenu Lotwy; ${ }^{*} z i r j a t z k r-z '$ ir'a' tok (655 pod Pskowem) - зере́moк w SRNG XI 266 też spod Pskowa.

Do sporadycznej nazwy białoruskiej ${ }^{*} z$ brědlzko $(z r e ł 1 k o-390$, tak samo w LAB III m. 46, s. 38 зрәлкó) nawiązuje łemkowskie зрілко (Hrinč II 184, ESUM II 279), a także forma żeńska зрíлкa, zanotowana przez Dzendzeliwskiego III (1993) m. $301 \mathrm{w}$ dwóch punktach: na północny wschód od Użhorodu i zrełka w Serpelicach koło Białej Podlaskiej (MAGP I 42, s. 120). Analo-

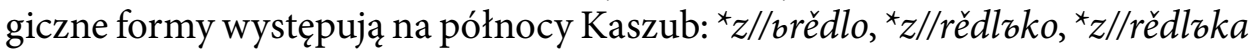
$(/ />d)$ w AJK IV 151, s. 36 zdžadue, $z d^{\check{c}}$ eukue, zdžad'eilke, zdřad'èlka, u Sychty VI 205 zdřadło.

Zapisana pod Nową Rudą w punkcie przesiedleńczym z ludnością spod Lwowa (276) źerńička ( ${ }^{*} z$ brbnič $\left.k k a\right)$ ma nawiązania w podawanych przez MAGP I 42, s. 120 formach źerniička, źorńička spod Sanoka (por. w kartotece SGPA też nazwę źernica 'źrenica' pod Lubaczowem).

Może odosobniony zapis ukraiński $z d r y k$ (487) należy zinterpretować jako ${ }^{*} z / /$ brikı $(/ />d)$, wtedy miałby nawiązanie w występujących na Kaszubach pod Kartuzami i Wejherowem formach $z d \check{r} i k, z d \check{r} y i k$, $z d \check{r}$ en $i k$ (Sychta VI 206, AJK VI 151, s. 36).

Od rdzenia ${ }^{\star} z b r$ - rozszerzonego o spółgłoskę $-k-{ }^{*} z$ brk- zanotowano w OLA tylko kilka derywatów. Nieliczne poświadczenia ma ${ }^{\star} z$ brkadlo: w Słowenii 'zo:rkalo (11) i 'zr:kału (17) oraz na Białorusi 'z'erkəła i obocznie 'z'erkal'ca - ${ }^{\star} z$ brkadlica (369). Znajdują one potwierdzenie w materiałach spoza OLA. Słoweńskie zŕkkalo 'źrenica' notuje Plet II 942 z liczną dokumentacją źródłową. Poza tym od XVI wieku bogato poświadczona jest formacja zŕklo - ${ }^{*} z$ brkdlo 'źrenica', utworzona bezpośrednio od czasownika bez przyrostka tematycznego ${ }^{\star} z$ brkti 'patrzeć' (Plet II 942, Bezlaj IV 426), później 'gałka oczna' (SSKJ V 945, Snoj 753). Sporadycznie zanotowane w XIX wieku u Levstika znaczenie 'źrenica' (powszechniej 'lustro, lusterko') miało też słwń. zŕcalo (Plet II 941). Formy białoruskie potwierdzają zapisy зе́ркъла i зе́ркъльциа w Atlasie białoruskim z tego samego punktu (LAB m. 46, s. 38). W HSBM XII 227-228 зеркало jest bogato poświadczone w znaczeniu 'lustro, lusterko’. Słownik współczesny TSBM nazwy tej już nie notuje. Dla formacji ${ }^{*}$ zbrkadlica potwierdzenia w materiałach spoza OLA nie znalazłem.

Zanotowane w punkcie słoweńskim 10 sporadyczne formy ' zarkalc, 'zarkilc można traktować jako kontynuanty pierwotnych ${ }^{\star} z$ zbrkalbcb lub ${ }^{*} z b r k(a) d l b c b$. Ich potwierdzenia spoza OLA nie znalazłem.

W materiałach spoza OLA można znaleźć jeszcze dalsze derywaty od

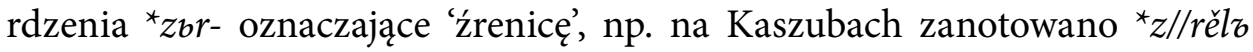


$(/ />d)$ : na północy $z d r i ̈ l$ (AJK IV 151, s. 36), na pograniczu powiatu kartu-

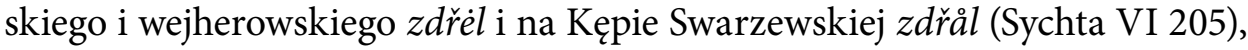
pod Wejherowem $z$ dřeńå - ${ }^{\star} z / /$ brěn - ${ }^{*} z / /$ brěn bje $(/ />d)\left(\mathrm{AJK}\right.$ IV 151, s. 36) oraz $z$ dŕl elovka - ${ }^{*} z / /$ brělovøka $(/ />d)$ na południowo-zachodnich Kaszubach (Sychta VI 206).

\section{B. Nazwy od rdzenia ${ }^{*}$ ględ-}

Formacji utworzonych od rdzenia czasownikowego ${ }^{*}$ ględ- oznaczających 'źrenicę' jest w OLA ponad 30. Grupuję je według sufiksów i przyrostków rozszerzających rdzeń czasownikowy.

Bezpośrednio od rdzenia utworzone są *ględy pl. 'źrenica', zapisane w punktach chorwackich 151 (glẽ:di) i 153 (gla'di:). Jako formę nawiązującą można tu podać jedynie chorw. glêd $\mathrm{m}$. w potocznym znaczeniu 'oko' (RSHJ III 333-334).

Dla sporadycznych w OLA zapisów chorw. gledạ::ča ( ${ }^{\star}$ ględača ?) w punkcie 29 i serb. ogle'dačka $\left({ }^{*}\right.$ oględačbka) w punkcie 169 nawiązań w innych źródłach nie znalazłem.

Od rdzenia ${ }^{\star}$ ględ- rozszerzonego przyrostkiem czasownikowym -al- zanotowano kilka sporadycznych formacji. Zapisaną w dolnołużyckim punkcie 236 formę gl’ẹdauks - * ględavzko potwierdza Schuster-Šewc I 292, przytaczając jako dolnołużyckie ekwiwalenty glědalko, glědawko dla górnołużyckiej nazwy hladančko - *ględančbko 'źrenica', natomiast Muka I 267 i Starosta 140 dla dolnołużyckiego glědałko dają tylko znaczenie 'lustro, lusterko'.

Chorwackie gle'da:lce - ${ }^{*}$ ględaloce chyba potwierdza podana przez Skoka III 656 bez podania znaczenia nazwa gledalce, natomiast innych nawiązań nie znalazłem. Nie mają też potwierdzenia bułgarskie sporadyczne zapisy w OLA: gleda'lec - * ględalbcb (116) i gledat'čec - * ględalč́cc (119).

Kilka formacji powstało od rdzenia ${ }^{\star}$ ględ- rozszerzonego przyrostkiem czasownikowym -ěl-, tj. od formy imiesłowu na $-l-$.

Dla formy ${ }^{\star}$ gledělbcb, notowanej w OLA zarówno w Bułgarii - glede'lec (114), gleda'łac (115, ten zapis można jednak traktować też jako kontynuant pierwotnego ${ }^{*} g l e ̨ d a l b c b$ ), jak i w Rosji - gl'a'd'el'ec (608 i podobnie 632, 657, 680), potwierdzeń spoza OLA brak.

Formy ${ }^{*}$ ględělbce, fonetycznie zakończone na -e (gl'a'd'el'ce - 659) lub na - o (gl'a'd'el'co-564,628,635), oraz * ględělbca, zakończone na -a (gl'a'd'elc'a-527, 677) zmapowano łącznie, ich ścisłe rozgraniczenie nie bardzo jest bowiem możliwe ze względu na częste -ə (we wszystkich pozostałych przykładach) w zakończeniu. Zresztą rosyjski słownik gwarowy też częściowo podaje je łącznie. Występują one w OLA w dwóch skupiskach: w okolicach Pskowa wzdłuż granicy 
z Estonią (też w p. 527 na terenie Estonii) i w okolicach Nowogrodu z pobliskimi punktami w okręgu leningradzkim i twerskim, a poza tym w dwóch punktach koło Kostromy $(670,687)$. Nazwy гляде́льце і гляде́льца rosyjski słownik gwarowy notuje właśnie też spod Petersburga, Nowogrodu, Pskowa i Tweru, a ponadto z terenów wykraczających poza siatkę punktów OLA znad Wiatki i pod Uralem (SRNG VI 227, por. też Dal I 360).

Zupełnie odosobnione formy gła'd'el'čblk i gła'd'il'č́blk, zapisane w p. 636 na północny wschód od Nowogrodu, zapewne należy wyprowadzać z pierwotnych ${ }^{\star} g L e ̨ d e ̌ l b c ̌ i k r, ~{ }^{*} g L e ̨ d i l b c ̌ i k r$, w których oczekiwane miękkie l' przeszło w twarde Ł pod wpływem wyrazu глаз 'oko'. Podobnie chyba należy tłumaczyć również sporadyczny zapis gl'il'z'el'ica w p. 629 pod Pskowem, gdzie $\mathrm{z}$ kolei w pierwotnym * ${ }^{\star}$ lęDélica wyraz глаз 'oko' wpłynął na przejście $D \mathrm{w} z$. Potwierdzenia wyżej podanych trzech form $w$ materiałach spoza OLA nie znalazłem.

Zapisy serbskiej nazwy *ględěljakr - gl'edé:l'ak (79 i podobnie 80, 82) mają potwierdzenie w notowanej przez RSHJ III 340 nazwie гледе́љьак 'źrenica' z Banatu i z okolic Svetozareva i Pirotu. Skok I 568 podstawy gledelw ogóle nie podaje, tylko gledal-. Podobną lokalizację dla nazwy глѐдёљка daje RSHJ l.c. W OLA zanotowano ją sporadycznie w p. 88 w północno-wschodniej Serbii koło Negotina ( $\left.g l e{ }^{\prime} d e l k a-{ }^{*} g l e ̨ d e ̌ l b k a\right)$.

Ta druga nazwa pojawia się także, niewątpliwie niezależnie, $w$ języku rosyjskim $w$ innym znaczeniu: гляд́́ z XVIII wieku, a гля́де́лки 'oczy' rosyjski słownik gwarowy ze słowników akademickich z 1895 i 1954 roku, jak też szeroko z gwar, nie tylko z objętych siatką punktów OLA, lecz także spod Uralu i z Syberii (SRNG VI 226-227).

Słownik Dala I 360 i SRNG 1.c. mają гля́déлки też w znaczeniu 'źrenica' spod Nowogrodu i z Permu pod Uralem.

Osobno potraktowano nazwy zawierające przyrostek czasownikowy -il-. Przeciwko łączeniu ich z podobnymi formacjami z przyrostkiem -ěl-świadczy nieco odmienna geografia i rosyjska tradycja leksykograficzna. Formację ${ }^{*}$ ględilb $C e(C>\check{c} \mathrm{w}$ p. 624) zanotowano w OLA w 10 punktach grupujących się głównie w okręgu wołogodzkim i w sąsiadujących punktach pod Kostromą (np. gl'a'd'il'ce, gl'e'd'il'c'o, gl'i'd'il'c'o itp.), poza tym w dwóch punktach koło Petersburga $(582,583)$, a postać * ględiloca - gl'e'd'ilca koło Wielska (574) na południu okręgu archangielskiego. Nazwę гляди́льuе w znaczeniu 'źrenica' notuje rosyjski słownik gwarowy spod Wołogdy i Nowogrodu, a także spod Permu na Uralu (SRNG VI 230). Za wariant tej nazwy może należy uznać oddzielnie u nas potraktowany sporadyczny zapis gl'il'd'il'ica - ${ }^{*}$ ględilica w p. 609 (na północ od Nowogrodu). 
Postać ${ }^{\star}$ ględętje (jest to dawne part. praes. act., por. Bezlaj I 146, Skok I 568) występuje w rozproszeniu w zachodniej części południowej Słowiańszczyzny, por. słwń. gle'dẹ:če (21) i gla'de:ičco (149), chorw. gledẹ:če (30), bosn. gléde:će (48) i serb. gléde:će (55), gledé:ce (77), gledé:će (81). Nazwa ta nie weszła do języków literackich, ale ma bogate poświadczenia w słownikach tych języków, por. słwń. gledêče n., gen. gledêčega i gledêča, też gledêčje, -čja i gledêšče (Plet I 216, ale SSKJ już jej

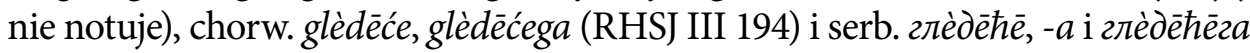
(RSHJ III 340). Skok l.c. podaje ponadto chorwacką postać gledečica.

Dla zanotowanej w trzech punktach bułgarskich wokół Sofii nazwy ${ }^{*}$ ględętjbcb - gledešltec $(122,123,127)$ potwierdzenia w innych źródłach nie znalazłem.

Dosyć wyraźny kompleks tworzy występująca w pewnym rozproszeniu w północnej Bułgarii i na wschodzie Serbii $(85,87)$ postać ${ }^{\star} g l e ̨ d b c b-g l e l d a c$, gle'dec, gli'dec itp. Ma poświadczenie zarówno w języku bułgarskim, por. гледéu w znaczeniu 'źrenica' w RSBKE I 184 i RBE III 200 (też 'tęczówka' i in.), jak i w serbskim, por. gledac, gen. gleca (RHSJ III 186) i глédau, глéu,a, w znaczeniu 'źrenica' określany jako regionalny, m.in. z poświadczeniami z Prizrenu, Niszu i Pirotu (RSHJ III 339). Dla zanotowanej sporadycznie formy ${ }^{\star}$ ględoce - glé:tce (69) i mac. gletce (94) spoza OLA potwierdzeń nie znalazłem.

Interesujące są dwa derywaty słowotwórcze zanotowane sporadycznie zarówno na południu - w języku serbskim, jak i na północy - w języku rosyjskim. Nazwa ${ }^{\star}$ ględen $b c b$ zapisana w OLA na południu Serbii gl'E'denac (84) i w Rosji na północ od Nowogrodu gl'a'd'en'ec (633) ma potwierdzenie w rosyjskim słowniku akademickim z 1895 roku i z gwary pod Nowosybirskiem. Nazwa ${ }^{*}$ ględenbce, zanotowana w OLA w środkowej i południowej Serbii gledá:nce 68, gledé:nce 78, gledé:nce 79, a w Rosji na północ od Kostromy gled'ince, w języku serbskim ma podobną lokalizację w RSHJ III 340 - гледе́нu,e 'źrenica', a ros. гляде́нияо 'źrenica' SRNG VI 228 podaje spod Uralu. Nazwy serbskie i rosyjskie powstały niewątpliwie niezależnie.

Zanotowane na północy okręgu wołogodzkiego *ględidlo - gl’ald'ilo (597), gl'e'd'iło (602) ma podobną, nieco szerszą lokalizację w tym samym okręgu, por. SRNG VI 230: гляди́ло 'źrenica'. Formacja ta ma częściej znaczenie 'lustro, lusterko', por. ros. гляди́ло (w SRNG l.c. jako znaczenie drugie), ukr. гляди́ло (Hrinč I 292, ESUM I 532), czes. hledidlo (Jg I 688, Kott I 431).

Sporadyczną formę białoruską ${ }^{*}$ ględrk $k a-\gamma^{\prime} l^{\prime} a t k a(344)$ pod Grodnem ma $\mathrm{z}$ tego samego punktu Atlas białoruski - гля́mка (LAB III m. 46, s. 38).

Dla sporadycznie zanotowanych w punkcie 181 na północy Czech postaci

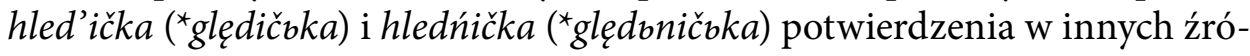
dłach nie znalazłem. 
C. Nazwy od rdzenia ${ }^{\star}$ patr-

Nazwy 'źrenicy' od czasownika *patriti 'patrzeć' znane są tylko z języka polskiego. W OLA zanotowano $\mathrm{w}$ rozproszeniu następujące formacje: ${ }^{*}$ patridlo - patšiduo, patšydůo, patřiduo itp. (250, 251, 259, 262-264, 304), ${ }^{*}$ patrid//loko (// > e wstawne) - pačydeukuo (255), poza tym sporadycznie *patręčıka - patšoncka (282) i patronzka - patrọka (285). Na podstawie polskich atlasów gwarowych (MAGP I 42, s. 121-122, AJK IV 151, s. 38-39, Pelcowa SłLub, Dejna AtlKiel VI 796, AGM VIII 382, s. 88-89), słowników i innych opracowań oraz kartoteki SGPA, które szczegółowo przedstawia AGM 1.c., znane jest znaczne bogactwo derywatów od rdzenia * patr-i ich szczegółowe zasięgi w gwarach polskich. Występują one na znacznym obszarze północnej części Polski „mniej więcej od Warszawy po Mrągowo i Starogard i od Złotowa po Łomżę" (MAGP I 42, s. 121-122, dalsze szczegóły w AGM VIII, s. 88-89): częstsze są ${ }^{*}$ patridlo - patrzydło, ${ }^{*}$ patrid//loko - patrzydłko, z zanikiem -l-patrzydko, ze wstawnym -e- patrzydełko, ${ }^{\star}$ patręč bka - patrzączka, rzadsze ${ }^{\star}$ patrjb - patrz między Złotowem i Sępólnem Krajeńskim, sporadyczne ${ }^{\star}$ patrjbko - pačko koło Bydgoszczy, ${ }^{\star}$ patronøka - patronka na Mazowszu, patrunka na Pomorzu i Kaszubach, patrolka, patrulka na Mazowszu, patruch na Mazowszu, patrzyk w Snopkach koło Piszu i inne.

\section{Nazwy od rdzenia *vid-}

Od czasownika *viděti 'widzieć' w materiałach OLA jest zaledwie kilka formacji słowotwórczych o ograniczonych zasięgach lokalnych.

$\mathrm{Na}$ Łużycach w Radworiu (237) zapisano dwie sporadyczne nazwy 'źreni-

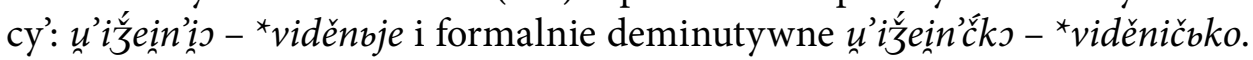
Pierwsza oznacza w języku łużyckim zazwyczaj 'widzenie', 'zmysł wzroku', druga 'zmysł wzroku', a także 'oczko' (Pful, Kral, Jakubaš), stąd mogło się rozwinąć przeniesione znaczenie 'źrenica'. Schuster-Šewc III 1597 podaje ponadto głuż. dial. widźeńko ( ${ }^{*}$ viděnıko) 'zmysł wzroku' i 'gałka oczna', a także 'źrenica'.

Zapisy nazwy v'izaduo - *vidědlo 'źrenica' w Wielkiej Wsi koło Pucka (242) i na południu Kaszub w Brzeźnie w pow. Chojnice (243) wnosi nową informację o szerszym zasięgu tej nazwy na Kaszubach. W AJK IV 151, s. 40 podano widziadło 'źrenicę' jedynie z Mechelinek koło Pucka (podobnie lokalizuje tę nazwę Lorentz PW III 957, powołując się na materiały AJK). Nawiązuje do niej víž́åtko ( ${ }^{*}$ vidědlıko) 'źrenica' z Wielkopolski pod Międzychodem (MAGP I 42, s. 121).

Dla sporadycznie zapisanej na północy Rosji, na wschód od Archangielska, nazwy ' $v^{\prime} i d$ ııšok - *vidyšskz (543) żadnych nawiązań nie znalazłem. 


\section{E. Nazwy od czasownika ${ }^{\star} z e ̌ t i$}

Do kręgu derywatów motywowanych przez czasowniki oznaczające 'patrzeć' można też zaliczyć derywaty od czasownika *zèti '(szeroko) otwierać, '(szeroko) otwierać się', 'patrzeć szeroko otwartymi oczami', 'patrzeć z otwartymi ustami', por. Kopečný 1960, 185-192 (z dalszą literaturą: Miklošič, Mladenov, Vasmer i in.). W OLA zapisano następujące derywaty: ${ }^{\star} z e ̌ n i-$ $c a,{ }^{*} z e ̌ n z k a$, sporadycznie ${ }^{\star} z e ̌ n z k r m$. Podstawę stanowił tu imiesłów na $-n$, a więc wymienione formacje strukturalnie miały znaczenie 'to, co się otwiera, 'to, co patrzy' lub pasywne 'to, co jest otwarte'.

W OLA *zènica 'źrenica' ma szeroki zasięg. Zanotowano ją w gwarach słoweńskich (zení:ca, 'zenica itp.), chorwackich ('zènica, 'zinica, zènca) i serbskich (zènica, zénica itp.), często obocznie z innymi nazwami. Z obszarem tym łączą się sporadyczne punkty sąsiadujące z Serbią: w północnej Macedonii $(93$ - zenica) i w północno-zachodniej Bułgarii (ze'nica - 118, 120). Poza tym zanotowano tę nazwę ( $\left.z^{\prime} i^{\prime} n y c^{\prime} a\right)$ w 7 rozproszonych punktach na terenie wschodniej Ukrainy i w południowej Rosji w ukraińskim językowo punkcie 843. Na mapie nazwa ta oznaczona jest szarą płaszczyzną z krzyżującą się ukośnie szrafurą.

Materiały spoza OLA dowodzą, że dawniej zènica 'źrenica' była znana szerzej. Powszechna była przede wszystkim na południu Słowiańszczyzny. Bogato poświadczona jest з W języku słoweńskim zeníca 'źrenica' ma liczne poświadczenia, jednak dopiero od XIX wieku (Plet II 914, Bezlaj IV 405), ale utrzymała się w języku literackim do dziś (SSKJ V 868). Na gruncie serbsko-chorwackim zënica, zjënica, zinica pojawia się już w XIV wieku i jest powszechnie używana do dziś, m.in. w zwrocie „чувати, пазити, гледати ... као зенииу ока" 'strzec pilnie', w nowszym piśmiennictwie, zwłaszcza w poezji i pieśniach, występuje też postać zjëna, zëna ( $\left.{ }^{*} z e ̌ n a\right)$, sporadycznie również zdrobnienie zjëničica, зёничищ, , por. RHSJ XXII 878-879, RSHJ VII 10-13, RSHKJ II 301, Skok III 656. Notują ją słowniki macedońskie, też w zwrocie „чува ... како зени́иата на окото" (RMJ I 260, TRJM II 213). Bogato poświadczona jest również w języku bułgarskim, m.in. w zwrocie „како зеницата на окото ...си пазя <вардя>" (RSBKE I 453, RBE V 906). Komisje narodowe OLA dla całej południowej Słowiańszczyzny nazwę *zènica uznały za literacką: słwń. zenica, chorw. zjenica, serb. зеница, mac. зеница (obok ирнка), bułg. зеница. $\mathrm{W}$ gwarach południowosłowiańskich natomiast dominuje, też $\mathrm{z}$ pewnymi ograniczeniami, tylko w części zachodniej.

We wschodniej Słowiańszczyźnie *zènica ma bogate poświadczenia w dawnych zabytkach. W języku staroruskim зтница znana była właściwie 
od XI wieku (1097) w znaczeniu 'źrenica' i 'oko', por. SrezMat I 1014, SDRJ III 436, SRJ XI-XVII, t. V 382. Słowniki te zazwyczaj oba te znaczenia podają łącznie. Ma liczne poświadczenia również w XVIII wieku (SRJ XVIII, t. VIII 174-175). Notuje ją także Dal I 680 i SSRLJ IV 1213. Ten ostatni słownik stwierdza jednak, że зени́u̧a jest dawną nazwą 'źrenicy' i 'oka'. W języku białoruskim зени́ца notowana jest od XVI wieku (HSBM XII 225), słownik języka współczesnego uznaje ją jednak za przestarzałą (зяниица - TSBM II 524, por. też ESBM III 359). Również w języku ukraińskim зънúua 'źrenica’ poświadczona jest od XVI wieku (SUM XVI-XVII, t. XII 242), także w zwrocie якъ зънииу заховати 'strzec szczególnie starannie' (z 1625 roku, por. SUM XVI-XVII, t. XI 25). W języku ukraińskim зінúu̧a 'źrenica’ utrzymała się do dziś (SUM III 574). Również komisja ukraińska uznała ją za nazwę literacką 'źrenicy' (obok чоловічок). Zestawienie materiałów ze źródeł historycznych $\mathrm{z}$ obecnym zasięgiem nazwy ${ }^{\star} z$ ěnica we wschodniej Słowiańszczyźnie wydaje się wskazywać, że może być tu ona dawnym cerkiewizmem.

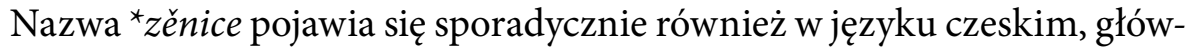
nie w znaczeniu 'gałka oczna', por. jej poświadczenia z XIX-XX wieku (Jg V 654, Kott V 455, PS VIII 389). Jest pożyczką, przejętą przez Presla, według Jungmanna i Kopečnego 1960, 186 z południowej Słowiańszczyzny, lub raczej za pośrednictwem języka rosyjskiego (SSJČ IV 719).

Derywat ${ }^{\star} z e \check{n} \succsim k a$ - zanotowano w OLA na niewielkim areale koło Mohylewa $(359,371,380)$ i na północ od Homla $(393)$ - w tych samych punktach też w Atlasie białoruskim zapisano зе́нка (LAB III 46, s. 38). Zupełnie sporadycznie odnotowano formę męską *zěnzkr - z'an'ok 'źrenica' w punkcie 811 na południu Rosji. Nazwy te w materiałach spoza OLA mają szersze nawiąza-

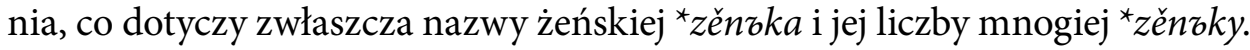
ESBM III 330 oprócz formy зе́нкa spod Mohylewa notuje też formę liczby mnogiej зе́нкi spod Witebska. Białoruskie зе́нка 'źrenica' ma kilka poświadczeń z XVI-XVII wieku (HSBM XII 225). Z dialektów ukraińskich znane są зінка, зінька 'źrenica' oraz pl. зіньки (ESUM II 264), ukr. зънка 'źrenica' notowana jest także w XVI-XVII wieku (SUM XVI-XVII, t. XII 242), a słownik współczesny notuje зі́ньки 'źrenice' z XX wieku (SUM III 574). Ros. зе́нки występowały zazwyczaj w znaczeniu 'oczy' (SRJ XVIII, t. VIII 175, SSRLJ IV 1213 - określa jako potoczne), ale rosyjski słownik gwarowy odnotowuje зе́нки, зе́ньки, зенки́ także w znaczeniu 'źrenica', m.in. z poświadczeniami z terenów objętych siatką OLA, a mianowicie spod Nowogrodu, Smoleńska, Kostromy i Tambowa (SRNG XI 263). Forma ${ }^{*} z e \check{n}$ øka została sporadycznie zanotowana też w języku serbskim w XIX wieku, por. зе̂нкa w RSHJ VII 13. 
Rosyjska forma męska *zěnøkı ma poświadczenie w znaczeniu 'źrenica' (lub może raczej 'tęczówka') z XV wieku, por. зънок w SRJ XI-XVII, t. V 382, a słownik gwarowy rosyjski notuje зено́к 'źrenica' spod Tweru (SRNG XI 263).

W materiałach spoza OLA odnotowano też formę rodzaju nijakiego *zěnøko 'źrenica', por. зéнко spod Smoleńska (Dal I 680, SRNG XI 263). W języku ukraińskim z XV wieku poświadczona jest nazwa osobowa ЗЂнько, Зънко, Зєнко (SSUM I 412).

\section{Nazwy motywowane przez wyrazy oznaczające obraz odbi- jający się w źrenicy}

Grupę te można podzielić na dwie podgrupy: A. Nazwy od wyrazu oznaczającego 'małego człowieka', 'człowieczka' i B. Nazwy tworzone od nazw 'dziecka', 'dziewczynki, 'lalki' (zabawki).

A. Nazwy od wyrazu oznaczającego 'małego człowieka'

Nazwy utworzone od zdrobnienia wyrazu *̌élověks tworzą w OLA dwa, zapewne niezależne, skupiska: na południu w dialektach bułgarskich i macedońskich oraz we wschodniej Słowiańszczyźnie, głównie na terenie Ukrainy i Białorusi (i na wschodnich krańcach Polski) oraz w rozproszeniu na terenie Rosji. Deminutywne nazwy oznaczające 'człowieka' wykazują podobny rozwój znaczeniowy '(mały, drobny) człowiek' > 'źrenica' również w innych językach indoeuropejskich i nieindoeuropejskich, por. SP II 130 (z dalszą literaturą).

$\mathrm{Na}$ południu zróżnicowane słowotwórczo formy tworzą rozległy areał obejmujący południową część Bułgarii, znaczną część Macedonii i dialekty słowiańskie w Grecji i Turcji. Na mapie oznaczony jest on jasną, szarą płaszczyzną ze szrafurą pionową. Najszerszy zasięg ma postać *čELoVěče $(E L>\emptyset$; $V>\emptyset)$, bardzo zróżnicowana fonetycznie, np. čoeče $(90,92,101)$, čo veče (103, 132), čove'če (117), ču'v'ače (140 i podobnie 851-853), čul' l’ače (112 i podobnie 113a, 139, 143, 850), ču'leči $(135,136,144)$ itd. Nazwę tę w postaci човечe notuje RMJ III 547 w znaczeniu 'mały człowiek', a znaczenie 'źrenica' określa jako dialektalne. W słownikach bułgarskich deminutivum човéчe występuje tylko w znaczeniu 'mały, drobny człowiek' (RSBKE III 627). Pozostałe formacje są sporadyczne. Postać *̌̌ELoVěčbcb $(E L>\emptyset ; V>\emptyset)$, zanotowaną w rozproszeniu $\mathrm{w}$ dwóch punktach macedońskich (čovečec - 100, čolvečec - 104) i jednym wschodniobułgarskim (čillačic - 137), potwierdzają słowniki, ale nie w znaczeniu 'źrenica': RMJ III 547 podaje човечеи jako deminutivum od чo- 
век, a RSBKE III 628 i BTR ${ }^{4} 1069$ чове́чеน, w znaczeniu 'biedny, nędzny człowiek’. Postaci ${ }^{*}$ ĚELoVěčblę $(E L>\emptyset ; V>\emptyset)$, zapisanej w południowo-zachodniej Bułgarii (čuvečlle - 125, ču'večle - 126) i *čeloVéčica $(V>\emptyset)$ - čillečica (129) w północno-wschodniej Bułgarii, w innych źródłach w znaczeniu 'źrenica' w ogóle nie znalazłem.

We wschodniej Słowiańszczyźnie występują postaci *čelověč $k$ r , *čelověčikz i *čelověčbko. Na mapie oznaczone są jednolitą szarą płaszczyzną. Najszerszy zasięg ma forma * čelověččkz. Tworzy ona zwarty areał obejmujący niemal całą Ukrainę (čoło' $v^{\prime} i c ̌ o k$, čułu'v'ičok itp.) i zachodnią (poza niewielką peryferią północną) Białoruś (čała'v'ečak, čoło'v'ičok, čoło'v'ečok itp.). Na Ukrainie brak jej na niewielkich peryferiach na południowo-zachodnim Zakarpaciu (chodzi tu o tereny między Winogradowem i Mukaczowem, co dokładniej pokazuje Dzendzeliwski III, 1993 m. 301) oraz na peryferiach północnych i wschodnich. Zresztą we wschodniej części Ukrainy często występuje ${ }^{*}$ čelověč $k$ r obocznie $\mathrm{z}$ nazwą ${ }^{\star} z o r c ̌ b k r$ (por. wyżej). Poza zwartym areałem przedstawionym za pomocą jednolitej szarej płaszczyzny nazwę tę zanotowano sporadycznie w rozproszeniu: we wschodniej Białorusi $(335,367,392)$, w północno-wschodniej Ukrainie (521), w punktach ukraińskich na terenie Rosji $(836,849)$, a nawet na północy Rosji (552, 571, 577).

Podobny zasięg nazwy *éelověč bkr na Białorusi w znaczeniu 'źrenica' prezentuje Atlas białoruski: różnice dotyczą punktów 353, 354 i 365, gdzie LAB III 46, s. 38 ma nieco inne dane. SłPogr V 398 przytacza nazwę чалаве́чак, чэлове́чак z zachodniej Białorusi i z terenu Polski spod Sokółki na Białostocczyźnie. Rosyjskie челове́чек 'źrenica' ma potwierdzenie u Dala IV 588 (bez lokalizacji) i u Vasmera ESRJ IV 329 spod Jarosławia. $\mathrm{Na}$ razie trudno dokładniej określić czas pojawienia się nazwy *čelověčokz w znaczeniu 'źrenica' na terenie wschodniosłowiańskim ze względu na brak odpowiednich tomów słowników historycznych. W HSBM XII 225 pod hasłem зенка 'źrenica' przytoczonо чоловьчок ze słownika Beryndy (1653). Dla języka ukraińskiego na to samo źródło powołuje się Tymčenko II 484. We wschodniej Słowiańszczyźnie ta nazwa 'źrenicy' jako nazwa literacka utrzymała się jedynie w języku ukrainskim: чолові́юк obok nazwy зіни́ия (SUM XI 351).

W gwarach rosyjskich na oznaczenie 'źrenicy' częściej notowano w OLA inną postać morfologiczną tego wyrazu, a mianowicie z sufiksem -ik: ${ }^{*}$ čelověčikr - c'eto'v'ec'ik (528), c'o'tov'ec'ik (533), c'e'łov'ic'ik (593 i podobnie 618, 774, 799). Zapisano ją też sporadycznie na Ukrainie: ča'tuviečik (441) i čała'v'eč̉ik (445). Rosyjska forma челове́чик w znaczeniu 'człowieczek', notowana ze słowników 
XVIII-wiecznych, a później jeszcze z Puszkina i w żartobliwym użyciu Majakowskiego, jest dzisiaj przestarzała (SSRLJ XVII 830).

Nazwę *čelověčzkz 'źrenica' zanotowano w OLA również z terenu Polski: z dwóch punktów przesiedleńczych: z punktu 257 pod Żaganiem we wskazującej na wpływ ukraiński postaci čłov'ičok i w punkcie 268 pod Trzebnicą w postaci čłov'eček oraz z punktu 324 na pograniczu ukraińskim pod Hrubieszowem w postaci čułuw'ičyk, z pełnogłosem i ukraińskim ukaniem. Nazwa człowieczek w znaczeniu 'źrenica' w Polsce ma w ogóle dosyć szeroki zasięg na całym pograniczu wschodnim, przy czym MAGP I 42, s. 121 też notuje formę z pełnogłosem čełowéček spod Bielska Podlaskiego. SGPA V $134 \mathrm{ma}$ *čelověčbkr w znaczeniu 'źrenica' spod Lubaczowa, Tomaszowa Lubelskiego, Biłgoraja, Hrubieszowa, Chełma, Włodawy, Radzynia Podlaskiego, Białej Podlaskiej, Siedlec, Sokołowa Podlaskiego, Siemiatycz, Bielska Podlaskiego i Augustowa, a nawet spod Ostrołęki, wreszcie z dawnych polskich dialektów kresowych na terenie Ukrainy i Białorusi. U Pelcowej (SłLub) człowieczek w tym znaczeniu tworzy zwarty areał na wschodzie Lubelszczyzny od Białej Podlaskiej aż po Tomaszów Lubelski.

W kilku rozproszonych wyspach zanotowano formę rodzaju nijakiego *čelověčbko. Niewielki zwarty areał tworzą trzy punkty na zachodzie Ukrainy po obu stronach Karpat: čułu'v'ičko (427), čoło'v'ičko (449) i čolọ v'ičko, čolọ'v'ičko (468). Zasięg tej nazwy na Ukrainie Zakarpackiej dokładniej wyznacza Dzendzeliwski III (1993) m.301: w zachodniej połowie Zakarpacia na południowych stokach Karpat powszechnie notuje postaci fonetyczne чоิлоิвічко, щ'ôлоิві́и'ко. Poza tym zanotowano w OLA tę nazwę w rozproszeniu na Białorusi koło Bobrujska čała'v'ečka (387, w tym samym punkcie tak samo w LAB III 46, s. 38 чалаве́чка), w Rosji koło Wołogdy c'iło'v'ic'ko (593), c'elo'v'ic'ko (616) oraz we wschodniej Polsce pod Mońkami cłov'ecko (287) i koło Biłgoraja čtuv'ičku (322). Znajomość nazwy człowieczko w znaczeniu 'źrenica' na wschodnich peryferiach Polski spod Lubaczowa, Biłgoraja, Zamościa, Chełma i Białegostoku potwierdzają MAGP I 42, SGPA V 134-135, Pelcowa SłLub i Kudzinowski (spod Knyszyna, por. Rembiszewska 2007, 137).

Nazwy *čelověčbkr, ‘čelověčsko w znaczeniu 'źrenica' na wschodnich peryferiach Polski ściśle nawiązują do dialektów ukraińskich i białoruskich. Ze względu na pojawiający się w nich pełnogłos oraz ukraińskie ukanie i ikawizm może należy mówić nie tylko o łączności terytorialnej, lecz raczej o pożyczce leksykalnej ze wschodu.

Podobną motywację jak formy deminutywne od *̌elověkr ma odosob-

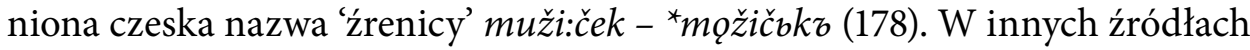
czeskich nazw mužík, mužíček w znaczeniu 'źrenica' nie znalazłem. 
B. Nazwy tworzone od wyrazów oznaczających 'dziecko', 'dziewczynkę', 'lalkę' (zabawkę).

Jest tu kilka nazw zajmujących rozleglejsze tereny i wiele zupełnie sporadycznych.

Zapis słoweński 'dišlica (1) i dwa zapisy z północno-zachodniej Chorwacji 'deklica (28) i dẹ:klica (35) uogólniam jako ${ }^{\star}$ děTblica $(T>k, \check{c})$ od podstawy dětę 'dziecko', przyjmując za Skokiem I 416 zmianę w podstawie * dětbla > dekla jak metla $>$ mekla i zmianę $k>c$ ze względu na częstą w językach słowiańskich oboczność $k: \check{c}$. Snoj 83 natomiast jako formę wyjściową przyjmuje *dětıkla lub *dètıkzla. Słoweńskie dẹkla, dẹklica i serbsko-chorwackie dëla, deminutivum deklica, mają dawne poświadczenia w znaczeniu 'dziewczyna', 'służąca' (Bezlaj I 97, Skok l.c.). Jedynie dla formy dẹćlica Plet I 126 podaje znaczenie 'źrenica', powołując się na XIX-wieczne materiały Cafa.

Dla kilku rzadszych nazw tego typu potwierdzenia znaczenia 'źrenica' w materiałach spoza OLA nie znalazłem. Odosobniony zapis słoweński

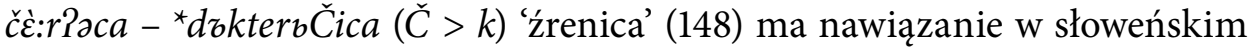
hčęrkica, hčęrrčica (Plet I 265, SSKJ I 785, Bezlaj I 192). Nazwa *čečica 'źrenica', zapisana w OLA w trzech punktach słoweńskich $(2,146,147)$, jest formą deminutywną od čéča, stanowiącego reduplikację języka dziecięcego (Bezlaj I 76, Snoj 68). W słownikach čéča, deminutivum ćéčica, występują tylko w znaczeniach 'dziecko, niemowlę', 'dziewczynka' i 'lalka' (zabawka). Zapisana sporadycznie w Chorwacji nazwa di'vicica - ${ }^{\star}$ děvičica (42) ma nawiązanie w poświadczonym od XVI wieku deminutivum djèvičica, дѐвичuи, notowanym jednak tylko w znaczeniu 'dziewczyna, dziewczynka' (RHSJ II 464, RSHJ IV 140, Skok I 416). Sporadyczne macedońskie detence - *dětenbce 'źrenica' (95) ma poza tym tylko znaczenie 'małe dziecko, dzieciątko', por. mac. детение (RMJ I 135, TRMJ I 437), podobnie bułg. дете́ние (RSBKE I 241, RBE III 755). Ukraińskie 'd’adečko - *dědočıko 'źrenica' (456) ma jedynie nawiązanie w notowanej przez Hrinč I 461 pieszczotliwej nazwie starszego mężczyzny дя́dечко. Zupełnie odosobnione są chorwackie nazwy 'źrenicy' ma:la: - ${ }^{*}$ malA (24) i mé?á:lica (22). Podstawowym znaczeniem dla chorw. mâlā i màlica jest 'dziewczynka' (por. też Skok II 374). Serbsko-chorwackie mâlica, мàлuu̧a w znaczeniu 'źrenica' notuje Nemanić w swoich czakawsko-chorwackich studiach z 1883-1884 roku (RHSJ VI 416, RSHJ XII 29).

Metaforyczne znaczenie 'źrenica' w nazwie *gzpanınøka zajmuje w OLA obszerny areał, oznaczony na mapie jasną, szarą płaszczyzną ze szrafowaniem ukośnym. Obejmuje on Czechy i Morawy (paneøka), Polskę (pańenka, pańeøka, pańanka itp.) i dwa punkty na północy Słowacji (paneøka - 215 pod Czacą, 227 koło Starej Lubowni we wschodniej Słowacji). Poza tym na półno- 
cy Słowacji występuje sporadycznie też pańička - ${ }^{*}$ grpaničıka (218 na Liptowie). Ze względu na wyjątkowe staroczeskie hpán obok pán (por. Boryś SE 410) przyjmuje się tu w nagłosie ${ }^{*} g$ z-: ${ }^{*}$ grpanınъka stanowi derywat od ${ }^{\star} g$ zpanına 'kobieta niezamężna', pierwotnie 'córka pana', co od ' gøpanı 'władca, pan'.

W OLA na terenie Polski poza częścią centralną notowano obocznie, a nawet wyłącznie nazwy inne. Dokładne zasięgi wyrazu panienka w znaczeniu 'źrenica' w gwarach polskich podają wcześniejsze opracowania, por. mapę 'źrenicy' w MAGP I 42 i mapy w atlasach regionalnych, jak Zaręby AJŚ IV m. 615, Dejny AtlKiel VI m. 796, AJK IV 151, s. 39 (tu panienka 'źrenica' występuje sporadycznie tylko poza Kaszubami), Pelcowa SłLub, AGM VIII m.382, s. 85-86, słowniki gwarowe, jak SGPK IV 27-28, kartoteka SGPA i inne opracowania przytoczone przez AGM l.c. Występuje ona, często obocznie z innymi nazwami, właściwie w całej Polsce, z wyjątkiem Kaszub, na peryferiach jednak rzadziej. Panienka 'źrenica' znana jest również w dialektach polskich na Śląsku Cieszyńskim (Basara 1975 m. 127) i na Spiszu w Słowacji (Sobierajski III, 1973, m. 228, notowaną tu sporadycznie formę pańička autor przypisuje wpływowi języka słowackiego). Osobne zagadnienie stanowi jej częsty brak na nowo osiedlonych ziemiach Polski zachodniej i północnej. Nie notują też wyrazu panienka w znaczeniu 'źrenica' słowniki języka ogólnopolskiego.

W czeskim języku ogólnym panenka (zwykle 'młoda dziewczyna', 'panna, dziewica' i 'lalka') pojawia się w znaczeniu 'źrenica' w XIX wieku (Jg II 24-25, Kott II 486-487), ma też późniejsze poświadczenia w tym znaczeniu w twórczości kilku autorów (PS IV/1, 57-58), a SSJČ II 501 znaczenie to określa jako specjalistyczne, medyczne.

Natomiast w języku słowackim panenka 'źrenica' jest w ogóle słabo poświadczona. HSSJ III 461 wyraz panenka podaje tylko w znaczeniach: 1. 'młoda dziewczyna', 2. rel. 'Panna Maria', a SSJ III 19 ponadto w znaczeniu 'lalka'. Słownik gwarowy słowacki ma panenka 'źrenica' tylko z trzech rozproszonych punktów: na północy spod m. Kysucké Nové Mesto (w nawiązaniu do poświadczeń z punktów 215 i 227 w OLA), na południu spod m. Rimavská Sobota i na środkowym zachodzie spod m. Topol'čany (SSN II 714-715). Natomiast nazwy panička w znaczeniu 'źrenica' SSN II 716 w ogóle nie notuje.

Kilka nazw 'źrenicy' łączy się z międzynarodowym słowem odonomatopeicznym języka dziecięcego ^beba, ${ }^{\star} b e b e$ 'dziecko'. W Chorwacji zanotowano formy: ${ }^{\star} b e b a$ - bé:ba (39), bè:ba (41), bé:bà (52), w dialektach macedońskich ${ }^{\star} b e b e-' b e b e(109,110) \mathrm{i}{ }^{\star} b e b b \check{C} e(\check{C}>c)-$ bepce $(106,108)$, w Bułgarii pl. *bebenbci - 'bebinci (124). W słownikach wymienionych języków nazwy te są notowane tylko w znaczeniu 'dziecko, niemowlę', nieraz też 'lalka', por. chorw. 
béba (RHSJ I 218, RSHJ I 364), mac. бебe (RMJ I 24, TRMJ I 98), też bułg. бéбe (RBE I 575-576), mac. бепче (TRMJ I 98), też bułg. бéбчe (RBE I 576) i sch. bëpče, bêpče (Skok I 128), bułg. бе́бенце (RBE I 576). Znaczenia 'źrenica' nigdzie nie znalazłem. Może należy tu zaliczyć i chorwacką nazwę 'źrenicy' bé:bica - ${ }^{\star}$ bebica (150), która przez RSHJ I 364 uważana jest za regionalną w tym znaczeniu, por. бèбuц $a^{2}$ (jedno poświadczenie z 1933 roku).

Podawana ze wschodniej Słowacji bapka - ${ }^{\star} b a b z k a(230)$ ma nawiązanie na pobliskim terenie. Dzendzeliwski III (1973) m. 301 odnotował w tym znaczeniu w trzech punktach koło Użhorodu бáбкa i бóбкa, a MAGP I 42, s. 121 (za AJPP m. 233) babka z pobliskiej wsi Kacze na Spiszu. Sobierajski III (1973) m. 228, s. 26 zakłada tu wpływ słowackiego wyrazu bábka 'lalka'. Słowacki słownik gwarowy jednak dla wyrazu bábka znaczenia 'źrenica' nie odnotowuje. Poza tym zapisano też postać ${ }^{\star} b a b i c a-{ }^{\prime}$ boga:bica (31). W materiałach spoza OLA serbsko-chorwackiego babica w znaczeniu 'źrenica' nie znalazłem.

Wyraz języka dziecięcego $\mathrm{z}$ charakterystycznym podwojeniem sylaby *l'al'a, *l'albka oznacza w językach słowiańskich najczęściej zabawkę dziecinną, mającą miniaturową postać ludzką. W metaforycznym znaczeniu 'źrenica' zanotowano w OLA *l'alıka i/lub dalsze formalne zdrobnienia *l'albčck $a$, *l'aličık $a$ głównie z dialektów polskich, czeskich, słowackich i białoruskich. Postać *l'alıka występuje głównie na terenie Polski: w Wielkopolsce (248, 254, 258), w północno-wschodniej części kraju $(266,274,275)$, pod Kielcami (301), w Cieszyńskiem (308) i w kilku punktach przesiedleńczych $(238,239$, 252, 267), poza tym w północno-zachodniej Białorusi $(331,332,337,339,341)$ i we wschodniej Słowacji $(231,232)$, formę rodzaju nijakiego *l'albko zapisano sporadycznie we wschodniej Słowacji (ĺalko - 228), formalne deminutivum *l'albčbka w północno-zachodniej Białorusi ('l'al'ačka - 334, 338, 339) i na południe od Mińska pod Soligorskiem ('l'al'ečka - 385), *l'aličıka zaś pod Cieszynem, zarówno po stronie czeskiej (ĺalička 207, Horní Lomna), jak i polskiej (lal'icka - 309, Wiślica, pow. Cieszyn).

Materiały spoza OLA uściślają zasięgi tych nazw w znaczeniu 'źrenica'. MAGP I 42, s. 122 za pomocą izoglosy wyznacza obszar środkowej Polski $\mathrm{z}$ brakiem nazwy lalka, a podaje ją z północno-wschodniej części Polski (dokładniej jej zasięg na północno-wschodnim Mazowszu po Ostrów i Ostrołękę wyznacza AGM VIII m. 382, s. 86-87), z zachodniej Wielkopolski, ze Śląska (tu jej północny zasięg wytycza za pomocą izoglosy Zaręba w AJŚ IV 615) i Małopolski (na Lubelszczyźnie jej sporadyczne poświadczenia przedstawia Pelcowa SłLub), wyjątkowe występowanie na północ od wyznaczonej przez MAGP granicy pod Kielcami dokumentuje Dejna AtlKiel VI m. 796. Brak nazwy lalka 
w znaczeniu 'źrenica' na całym obszarze objętym przez AJK (IV m. 151, s. 40). Wyjątkowo zanotowaną nazwę lalka 'źrenica' w jednym punkcie pod Wejherowem autorzy AJK słusznie przypisują lokalnemu wpływowi pożyczki niemieckiej pupka 'źrenica' (por. niżej). Lalka 'źrenica' występuje też dosyć często w dialektach polskich na Spiszu, również po stronie słowackiej (Sobierajski III, 1973, m. 228, s. 25). Nazwę lalka 'źrenica' jako gwarową podaje SJPD IV 14, przytaczając cytat z XIX wieku. Na gruncie czeskim, jak się zdaje, w znaczeniu 'źrenica' znane jest tylko formalne deminutivum lalička (por. niżej). Na Słowacji podstawowa l'al'ka 'źrenica' jest poświadczona zupełnie sporadycznie na samym wschodzie kraju pod Vranovem (SSN II 22). Pojawia się z rzadka na Ukrainie Zakarpackiej: u Dzendzeliwskiego III (1973) m. 301 w dwóch punktach (pod Mukaczowem i nad górnym biegiem rzeki Borżowa), bez lokalizacji jako gwarową podaje ją też ESUM III 338. Poza tym na Łemkowszczyźnie występuje forma rodzaju nijakiego ля́лько 'źrenica' (z Werchratskiego, por. Hrinč II 392, Sławski SE IV 33-34, ESUM 1.c.). W innych źródłach z Białorusi ля́лька poświadczona jest nie tylko z tych samych punktów (LAB III m. 46, s. 38, SłPogr II 715), lecz także nieco szerzej: spod Soligorska (ESBM VI 120121), z Nosoviča bez ściślejszej lokalizacji (Sławski SE IV 33-34).

Formę *l'al'bčbka z tych samych punktów co OLA ma także Atlas białoruski: ля́лячка і ля́лечка (LAB III m. 46, s. 38), natomiast forma *l'aličbka na podstawie źródeł spoza OLA tworzy niewielki areał na pograniczu polsko-czesko-słowackim: MAGP I 42, s. 120, częściowo uwzględniając materiały AJPP, nazwę lalička notuje z Istebnej pod Cieszynem, z Czarnego pod Czacą, z Pogórza pod Namiestowem (Námestovo), na słowackiej Orawie i z miejscowości Ujsoły pod Żywcem. W okolicach Żywca ściślej jej zasięg wyznacza Zaręba AJŚ IV m.615, na południe od Cieszyna aż poza Jabłonków po obu stronach czesko-polskiej granicy państwowej Basara 1975, m. 127, s.64, spod Jabłonkowa podaje ją też Kellner VLN II 210, a Sobierajski III (1973) m. 228, s. 25 z dialektów polskich na polskim i słowackim Spiszu, wreszcie słowacki słownik gwarowy spod Spiskiej Nowej Wsi (SSN II 22). Ze względu na sufiks -ička dla dialektów polskich należy przyjąć wpływ słowacki (por. Sobierajski l.c.). Gwary polskie na Słowacji świadczą, że wyraz ten w znaczeniu 'źrenica' może być znany szerzej w gwarach słowackich, niż to podaje słowacki słownik gwarowy.

Podobną motywację od obrazu 'dziewczynki', 'lalki' odbijającego się w źrenicy ma kilka wyrazów obcego pochodzenia.

Nazwę * pupila 'źrenica' zanotowano w OLA w dwóch punktach polskich: pupela pod Oleckiem (265) i pup'ila pod Prudnikiem (288). Materiały spoza OLA wskazują na szerszą znajomość tego wyrazu w gwarach Polski. MAGP I 42 poświadcza ją szerzej z Mazur (dwukrotnie spod Olecka i spod Giżyc- 
ka - pupéla) i z Warmii (z Bredynka pod Reszlem - popila) oraz z północnej Wielkopolski spod Chodzieży. AJK IV 151, s. 38 podaje pupila, pupyla, popila i popela nie tylko w dwóch wyraźnych skupiskach na południu Kaszub (4 punkty) i na Krajnie (3 punkty), lecz także z Wierzchucina na północy i z Trąbek Wielkich pod Gdańskiem. Zaręba AJŚ IV m. 615 ma puṕila i popila szerzej ze Śląska, mianowicie spod Prudnika, Niemodlina, Kluczborka i Oleśnicy. Ze względu na zasięg geograficzny tego wyrazu należy tu przyjąć pożyczkę niem. Pupille 'źrenica' (por. też Hinze DLK 376), a nie bezpośrednio ze stanowiącej źródło nazwy niemieckiej łac. pūpilla 'mała dziewczynka', 'źrenica' (por. EWD II 1060, Kluge ${ }^{23}$ 655). Z niemieckiego zapożyczono niezależnie też popile 'źrenica' w dialekcie czeskim pod Kudową (Siatkowski DCK II 76).

Wyraz ten pojawia się sporadycznie w niektórych literackich językach słowiańskich jako specjalistyczna nazwa anatomiczna 'źrenicy', por. słwń. pupila (SSKJ IV 289), serb. nynùлa w tłumaczeniu z czeskiego (RSHKJ V 293), czes. pupilla (Kott II 1253), pupila (PS IV/2, 557, SSJČ II 1180, też jako termin optyczny), słc. pupila (SSJ III 668, też jako termin optyczny), dłuż. pupila (Starosta 397) - komisja łużycka OLA podała ją również jako dolnołużycką nazwę literacką. W materiałach spoza OLA w znaczeniu 'źrenica' sporadycznie pojawia się także pożyczka łacińskiej formy męskiej pūpillus, por. sch. pupîlj 'źrenica' (Virje i Fancev, por. RHSJ XII 681, Skok III 79); częściej występuje pupil w znaczeniu 'ulubieniec, faworyt', u nas przejęty zapewne za pośrednictwem francuskim (por. Bańkowski SE II 966).

Zapożyczenia niem. Puppe 'dziewczynka', 'lalka' (zabawka), 'źrenica' (z łac. puppa > pūpa 'dziewczynka', 'lalka', por. EWD II 1060-1061, Kluge ${ }^{23}$ 655-656) pojawiają się w derywowanych postaciach ${ }^{*}$ puproka $\mathrm{i}{ }^{\star}$ pupica $\mathrm{w}$ znaczeniu 'źrenica' w trzech odległych wysepkach: w zachodnich punktach słoweńskich 'pupka (3) i pù:pca (4), we wschodniej Słowacji popka $(227,229)$ oraz w Polsce na Kaszubach w Mirachowie 'puupka (244) i na południu w Karsinie w pow. chojnickim pupka (245). W innych źródłach zapożyczenie niemieckie pupa, pupka i pupica notowane jest zazwyczaj w znaczeniach 'dziewczynka' i 'lalka', a znaczenie 'źrenica' w wyrazie pupka odnotowano powszechniej na Kaszubach (AJK IV m. 151, s. 37; sporadycznie pod Wejherowem zapisano w tym znaczeniu formę niesufigowaną pupa), Sychta IV 223 zaś podawał ją tylko z Kaszub północnych i środkowych. Poza tym znajdujemy jedynie sporadyczne poświadczenia w znaczeniu 'źrenica': w MAGP I 42, s. 121 spod Kościerzyny (popka) i z północno-zachodniej Wielkopolski spod Czarnkowa (pöpka) oraz z dialektów polskich na Spiszu pod Kieżmarkiem i Lubownią (Sobierajski III, 1973, m. 228, s. 25). Na tych różnych terenach mamy zapewne do czynienia z pożyczkami niezależnymi. 
Niewielką wysepkę w południowej części Słowenii tworzą derywaty od punca 'dziewczyna', 'lalka': *punčıka ('pu:nčka - 5, 12, pù:nčka - 14, pọ̀:nčka - 16) i punčica ('punčca - 6), mające znaczenie 'źrenica'. Sporadyczne poświadczone są one w innych źródłach, por. pûnčka 'źrenica' z XIX wieku u Plet II 363 (SSKJ IV 288 już jednak tego znaczenia nie odnotowuje) i pûnčica, púnčica 'źrenica' u Plet II 363 i w SSKJ IV 288. Gutsmann w XVIII wieku odnotował nazwę punčica w znaczeniu 'gałka oczna' (Bezlaj III 136). Częściej wyrazy te notowane są w znaczeniach 'dziewczynka' i 'lalka'. Według Bezlaja l.c. i Snoja 515 podstawowa punca stanowi zapożyczenie włos. pulcella 'dziewczyna' (por. też dawne hiszpańskie puncella), utworzonego od łac. pullus 'młodzieniec'. Przyjmowano też, zdaniem Bezlaja i Snoja bezpodstawnie, pożyczkę niem. Punze(n), Bunze(n) 'żeński organ płciowy', 'dziewczyna' z łac. punctiō.

\section{Nazwy motywowane czarnym kolorem 'źrenicy’}

Jeśli się weźmie pod uwagę tak charakterystyczny dla 'źrenicy' kolor czarny, dziwi mała liczba derywatów od przymiotnika *čbr $n \zeta$, które ją oznaczają W dialektach słowiańskich tworzą one kilka niezależnych wysepek.

Dla nazwy ${ }^{*}{ }^{*}$ br $r n O$, zanotowanej w dwóch punktach chorwackich 'černo (146a) i 'črno va ùoki (148a) oraz na Łużycach te črrne uo uọ̆ku (235), brak potwierdzenia w innych źródłach.

Macedońską nazwę *̌̌brbrnøka, zapisaną w pięciu punktach (carnka - 99, 'crnka - 100, 102, 'čarnka - 107, c'royka - 113), poświadcza słownik języka macedońskiego црнка 'źrenica' (RMJ III 525).

Kilka derywatów od przymiotnika “čbrn $n$ tworzy dosyć rozległy, choć niezbyt zwarty areał w północnej Rosji aż po linię wytyczoną przez punkty 571, 573, 577, 627 (jego południowy zasięg wyznacza izoglosa $\mathrm{nr} 1$ ). Są to

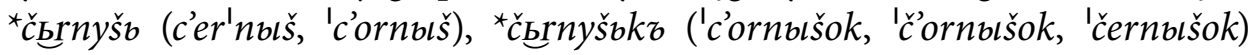
i ‘̌́brhnyšbko ('ćornuš̌ko, 'c'ernblško). W źródłach spoza OLA znalazłem jedynie черниіш , i to w innych znaczeniach: u Dala IV 595 'smagły, śniady człowiek', w SSRLJ XVII 931 o ciemno ubarwionych ptakach.

\section{Nazwy motywowane przez wyrazy oznaczające niewielkie przedmioty kuliste, świecące i błyszczące}

Notowano je w OLA zazwyczaj sporadycznie, ale mają one analogie w innych źródłach. Ze względu na bardzo przejrzystą motywację należy zakładać, że mogły powstać zupełnie niezależnie. 
Bułg. zar'no, 'zarnu - *zbrno 'źrenica', zapisane w rumuńskim Banacie (167), ma analogię w bułg. зб́рно, зърнó 'ts.', podawanym przez BER I 669-670 z terenu Grecji spod miejscowości Kukusz, oraz w dolnołużyckich odpowiednikach wóćkowo zorno, zornjatko i zernko dla niem. Pupille w słowniku Rězaka 760. Dla brus. 'z'ern'etka - ${ }^{\star} z$ brnetzko/ ${ }^{\star} z$ brnetzka 'źrenica' (398, tak samo w LAB III m.46, s. 38 зе́рнетка) innych potwierdzeń nie znalazłem. Brus. зе́рнетка, зярня́тка оznacza zwykle 'ziarenko' (TSBM II 524, ESBM III 330), podobnie ich gwarowe ekwiwalenty rosyjskie зе́рнетко, зе́рнятко, зерня́тко (SRNG XI 267-269).

Nazwa *̌̌očbka, będąca wtórną formą od mającej w języku czeskim bardzo różne postaci fonetyczne wyjściowej formacji ${ }^{\star}$ sočevica o pierwotnym znaczeniu 'soczewica' (por. Machek ES-2, 106, Boryś SE 566 s.v. soczewica), została zapisana w OLA w kilku punktach południowoczeskich (čočka i podobnie - 191, 194, 201) w znaczeniu 'źrenica'. Mamy tu zapewne do czynienia z przeniesieniem znaczenia 'soczewka' na 'źrenica', w słownikach czeskich čočka ma właśnie m.in. znaczenie 'soczewka' (Jg I 310, Kott V 1217, PS I 335, SSJČ I 263 anatomicznie ‘část oka lámající světlné paprsky’).

Zanotowane w OLA na północy Rosji 'jadrblško - *jędryšbko 'źrenica' pod Kargopolem na południu guberni archangielskiej $(569,571)$ i pod Babajewem (587) na zachodzie guberni wołogodzkiej jest nieznaną z innych źródeł innowacją semantyczną rosyjskiego wyrazu я́dрышко 'ciało kuliste', 'kuleczka, jąderko' (Dal IV 673, SSRLJ XVII 2044).

Nazwę gauka - *galzka 'źrenica' zanotowano w OLA tylko w punkcie 246 pod Starogardem Gdańskim. Właśnie tu tworzy ona zwarty areał oznaczony w AJK IV 151, s. 34-35 kreskowaną płaszczyzną. Obejmuje on południowo-wschodnie dialekty kaszubskie, północną Tucholszczyznę i Kociewie (niemal od południowej granicy powiatu gdańskiego aż po Świecie). Właśnie $\mathrm{z}$ tych stron podaje gałkę też MAGP I 42, s. 121. Poza tym gałka 'źrenica' była notowana w dialektach polskich zupełnie sporadycznie: $\mathrm{w}$ północnej Wielkopolsce pod Wyrzyskiem (MAGP l.c. i kartoteka SGPA), w kilku rozproszonych punktach na Mazowszu (AGM VIII 382, s. 88), podobnie na Lubelszczyźnie (Pelcowa SłLub). Są to doraźne, niezależne przesunięcia semantyczne w nazwie gałka 'drobny przedmiot kulisty' > 'gałka oczna' > 'źrenica'. Wyraz ten można łączyć $z$ przymiotnikiem * gol乃 'goły', może też być pożyczką od śrwniem. galle 'obramowanie, bąbel' < łac. galla 'galas' (Sławski SE I 253). W OLA, chyba niesłusznie, wyraz ten nie został włączony do zestawienia pożyczek obcych.

Odosobniona pupu'lica w chorwackiej wyspie językowej na południu Włoch (44a) stanowi zapewne rozbudowany derywat ${ }^{*} p$ ppulica od ${ }^{\star} p q p-p \hat{u} p$ 
'pąk, pączek'. Przesunięcia semantyczne mogły wywołać regionalne znaczenia serbsko-chorwackiego püpoljica, pùpuljica 'kamień ogładzony przez wodę' (Skok III 78) lub 'owoc jałowca', 'roślina mająca kuliste owoce' (RSHJ V 294, RHSJ XII 683).

Do omawianego typu motywacyjnego można zaliczyć jeszcze kilka sporadycznie zapisanych nazw, które też mają nieraz potwierdzenie w materiałach spoza Atlasu: bułg. $3^{1} v^{\prime} a z d a-{ }^{*}$ gvězda (141), por. bułg. 3вездá 'gwiazda', ale też pol. gviözda v ueku 'źrenica' ze Studzienic pod Bytowem (MAGP I 42, s. 121), serb. da'nica - ${ }^{*} d$ bnınica (72), por. sch. dànica 'jutrzenka, gwiazda poranna', ros. zna'č’ok - ${ }^{\star} z n a c ̌ z k z$ (822), por. ros. значoк 'znak, znaczek', ros. xrus'tal' - 'x rust als (803), por. ros. хруста́ль 'kryształ, kryształek', chorw. 'punkt - ${ }^{\star}$ punktъ (147a) z łac. part. perf. rodzaju nijakiego punctum (Skok III 75-76), por. sch. dawne i rzadkie pünkt 'punkt, kropka', częściej pünat, punt, punkat itp. od XV wieku (por. RHSJ XII 661, RSHJ XII 667, RSHKJ V 290, Skok l.c.). Ciekawe, że na Kaszubach też zanotowano punkt, a także wyraz kropka w znaczeniu 'źrenica' (AJK IV 151, s. 40, 41).

$\mathrm{Z}$ innych źródeł należy wymienić przede wszystkim jabłko, jabłuszko z północy Kaszub i jagoda, jagódka z południowo-zachodnich Kaszub (AJK IV 151, s. 37, 40, w MAGP I 42, s. 121 jagódka spod Żywca).

Zupełnie niezrozumiała jest kryńica - ${ }^{*}$ krinica (?) z polskiego punktu przesiedleńczego pod Trzebnicą (268).

\section{Zdrobniałe nazwy oka}

Zdrobniałe nazwy 'oka’ można uznać za brak właściwej odpowiedzi na pytanie o wyraźnie wyróżniającą się istotną jego część, jaką stanowi 'źrenica'. Podam je jednak ze względu na dosyć częste ich poświadczenia w OLA.

Deminutywne ${ }^{\star}$ očbko zapisano na północy Białorusi: 'vočka $(335$ - tu w tym samym punkcie Atlasu białoruskiego jest вóчкa) oraz w kilku rozproszonych punktach na Ukrainie: wočlko (405), očlko (460), očl ko (464) i 'v'ič'ko (497). Por. też očko 'źrenica' w MAGP I 42, s. 121 u przesiedleńców z Ukrainy.

Od *glazъ 'oko' zapisano w pojedynczych punktach kilka form deminutywnych na oznaczenie 'źrenicy': na Białorusi $\gamma^{\prime}$ taska - ${ }^{*}$ glazøka (335), w Rosji gła'z'el'co - *glazělbce (587), a w p. 637 gła'z'el'ic - * glazělbcb oraz gła'z'en'čblk, który można wywodzić z pierwotnej formy ${ }^{*}$ glazenbčikr lub ${ }^{*}$ glazělbčikr ze względu na liczne formacje $\mathrm{z}$ czasownikowym elementem -ěl- od rdzenia *ględ- (por. wyżej) z wtórnym zastąpieniem spółgłoski -l- przez - $n$ - pod wpływem wyrazu глаз. 
Mimo iż nazwy 'źrenicy' są znacznie przemieszane i często występują obocznie z innymi nazwami w tych samych punktach, a poszczególne leksemy mają niezbyt ostre granice zasięgów, można wyznaczyć kilka względnie wyraźnych, choć niezbyt zwartych areałów.

W Rosji oraz we wschodnich częściach Białorusi i Ukrainy dominuje na$\mathrm{zwa}{ }^{\star} z / /$ orčbkz $(/ />d)$, por. na mapie 1 izoglosę $\mathrm{nr} 2$. Na terenie Rosji w areale tej nazwy można wydzielić obszar odrębnego lub obocznego występowania

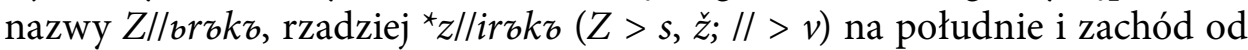
Moskwy, nazw ${ }^{*}$ ględělbce, ${ }^{\star}$ ględélbca $\mathrm{i}{ }^{\star}$ ględél locb w okolicach Pskowa i Nowo-

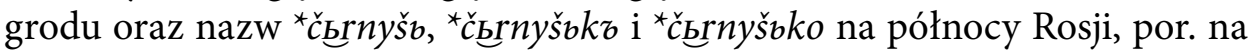
mapie 1 izoglosę nr 1.

Dla Polski i Czech charakterystyczna jest nazwa ${ }^{*} G$ bpanınъka $(G b>\emptyset)$ - por. na mapie 1 jasną, szarą płaszczyznę z ukośną szrafurą, dla Polski także *zbrènica.

$\mathrm{Na}$ Ukrainie i we wschodniej Białorusi dominuje nazwa *̌̃elověčbkr (i sporadycznie *čelověčbko) - por. na mapie 1 szarą jednolitą płaszczyznę, a w południowej Bułgarii, w Macedonii i w słowiańskich punktach na terenie

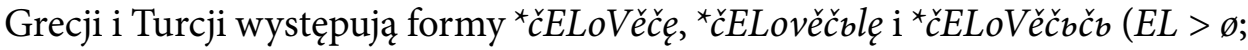
$V>\emptyset)$ - por. na mapie 1 jasną szarą płaszczyznę z pionową szrafurą.

$\mathrm{Na}$ terenie serbsko-chorwackim $\mathrm{z}$ pewnymi nawiązaniami w Słowenii i północno-zachodniej Bułgarii przeważa nazwa *zěnica, oznaczona na mapie 1 szarą płaszczyzną z krzyżującą się szrafurą.

Wiele nazw ma ograniczone zasięgi, np. ${ }^{*} z o r b n i c ̌ c k a-$ głównie na Słowacji, ${ }^{\star} z$ zrěnøka - przeważnie na Białorusi, ${ }^{\star} z$ zrjačıka - przede wszystkim w zachodniej części Ukrainy Zakarpackiej itd. Źródła spoza OLA zazwyczaj potwierdzają, uściślają lub nieco rozszerzają granice tych formacji lokalnych.

Nazwy pojawiające się sporadycznie na terenach odległych od ich podstawowych, zwartych zasięgów zazwyczaj nie przemawiają za ich wcześniejszą wspólnotą. Przejrzysta motywacja pozwala przyjmować niezależne innowacje analogiczne. Ciekawe, że nawet zupełnie odosobnione i niespodziewane nazwy, jak np. ${ }^{\star}$ gvězda, ${ }^{\star}$ punktъ itp., mają często potwierdzenie w materiałach spoza OLA.

Na mapie 2 najbardziej widoczne są dwa typy motywacyjne: od czasowników o znaczeniu 'patrzeć', który występuje w przeważającej części terytorium słowiańskiego (areał oznaczony jednolitym szarym kolorem), oraz od wyrazów oznaczających osoby i przedmioty odbijające się w 'źrenicy', który jest częściej reprezentowany w zachodniej części Ukrainy, w zachodniej 
Białorusi, w przeważającej części Polski, w Czechach i na Morawach, w północno-wschodnim skrawku Słowacji, a także w Macedonii, południowej Bułgarii i w punktach słowiańskich na terenie Grecji i Turcji (areał oznaczony szrafurą poziomą). Oba typy notowano w pewnym przemieszaniu, zwłaszcza na wschodzie Ukrainy i Białorusi, a na terenach pogranicznych widoczne są pasy przejściowe. Na mapie 1 to przemieszanie nazw i pograniczne pasy przejściowe na Ukrainie i Białorusi są technicznie przedstawione nieco inaczej.

Nazwy motywowane czarnym kolorem 'źrenicy' (oznaczone szrafurą ukośną) grupują się przede wszystkim w północnej Rosji i w południowych dialektach macedońskich, ale sporadycznie pojawiają się też na terenie Austrii i na Łużycach. Typy motywacyjne od nazw oznaczających przedmioty kuliste, świecące i błyszczące (oznaczone szrafurą pionową) oraz od nazw będących zdrobniałymi nazwami oka (oznaczone przecinającą się podwójną szrafurą ukośną) są zupełnie sporadyczne i występują w znacznym rozproszeniu.

\section{Literatura}

AGM - Atlas gwar mazowieckich, t. I oprac. H. Horodyska-Gadkowska, A. Strzyżewska-Zaremba, t. II-X oprac. A. Kowalska, A. Strzyżewska-Zaremba, Wrocław 1971-1992.

AJK - Atlas językowy kaszubszczyzny i dialektów sąiednich, oprac. przez Zespół Zakładu Słowianoznawstwa PAN pod kier. Z. Stiebera, od z. VII pod kier. H. Popowskiej-Taborskiej, I-XV, Wrocław 1964-1978.

AJPP - M. Małecki, K. Nitsch, Atlas językowy polskiego Podkarpacia, Kraków 1934.

Bańkowski SE - A. B a ńkowski, Etymologiczny słownik języka polskiego, I-II, Warszawa 2000. B a s a r J., Słownictwo polskich gwar Śląska na terenie Czechosłowacji, Wrocław 1975.

BER - Български етимологичен речник, ред. Вл. Георгиев (И. Дуриданов, М. Ра чева, Т. А. Тодоров), София $1971 \mathrm{i} \mathrm{n.}$

B ezlaj F., Etimološki slovar slovenskega jezika, I-IV, Ljubljana 1977-2005.

Boryś SE - W. Bor yś, Słownik etymologiczny języka polskiego, Kraków 2005.

$\mathrm{BTR}^{4}$ - Български тълковен речник, ред. Л. А ндре й чи н и др., четвърто издание допълнено и преработено от Д. Попов, София 1996.

$\mathrm{Dal}$ - Вл. Да ль, Толковый словарь живого великорусского языка, I-IV, Москва 1955-1956.

Dejna AtlKiel - K. Dejn a, Atlas gwarowy województwa kieleckiego, I-VI, Łódź 1962-1968.

Dzendzeliwski 1993 - Й. О. Дзедзелів ськ и й, Лінгвістичний атлас укранських народних говорів Закарпатскої області України (Лексика), ч. ІІІ, Ужгород 1993.

ЕSBM - Этыммалагічны слоўнік беларускай мовы, рэд. В. У. Мартын аў, Мінск 1978 i n. ESUM - Етимологічний словник української мови, ред. О. С. Мельн и чук, Київ 1982 i n. 
Słowiańskie nazwy 'źrenicy' w świetle materiałów gwarowych i źródeł historycznych 171

EWD - Etymologisches Wörterbuch des Deutschen, 2. Aufl., durchgesehen und ergänzt von W. Pfeifer, I-II, Berlin 1993.

Hinze DLK - F. H in ze, Wörterbuch und Lautlehre der deutschen Lehnwörter im Pomoranischen (Kaschubischen), Berlin 1965.

Hrinč - Б.Грін ченко, Словарь украйнської мови, I-IV, Київ 1907-1909.

HSBM - Гістарычны слоўнік беларускай мовы, рэд. А. Жу раўскі, Мінск 1982 i n.

HSSJ - Historický slovník slovenského jazyka, red. M. Majt á n, I-VII, Bratislava 1991-2008.

Jg - J. Jung ma n n, Slovník česko-německý, I-V, Praha 1835-1839.

Kellner VLN - A. Kellner, Východolašská nářečí, I-II, Brno 1946-1949.

Kluge EW $\mathrm{EW}^{23}$ - F. Klu ge, Etymologisches Wörterbuch der deutschen Sprache, 23. Aufl., bearb. von E. Se ebold, Berlin-New York 1995.

Kopečný F., Slovanské zěnica, „Slavia” XXIX (1960), s. 185-192.

Kott - F. Š. Kott, Česko-německý slovník, zvláště gramaticko-frazeologický, I-VII, Praha 1878-1893.

LAB - Лексічны атлас беларускіх народных гаворак у пяиі тамах, рэд. М. В. Бірыла, Ю. Ф. Мацкевіч, Мінск 1993-1998.

Lorentz PW - F. Lorentz, Pomoranisches Wörterbuch, fortgeführt von F. Hin ze, I-V, Berlin 1958-1983.

Machek ES-2 - V. Machek, Etymologický slovník jazyka českého, Praha 1968.

MAGP - Mały atlas gwar polskich, oprac. przez Pracownię Atlasu i Słownika Gwar Polskich Zakładu Językoznawstwa PAN w Krakowie pod kier. K. Nitscha, od t. III pod kier. M. Karasia i Z. Stamirowskiej, od t. IX pod kier. M. Karasia, I-XIII, Wrocław 1957-1970.

MSČS - J. B ělič, A. Ka miš, K. Kučera, Malýstaročeský slovník, Praha 1978.

$\mathrm{Mu}$ k a A., Słownik dolnoserbskeje rěcy a jeje narěcow. Wörterbuch der niedersorbischen Sprache und ihren Dialekte, I-III, Petrograd-Praha 1911-1928.

OLA 1 - Общеславянский лингвистичеслий атлас. Серия лексико-слово-образовательная, t. 1: Животный мир, ред. В. И. А в анесов, В. В. Ив анов, Москва 1988 і n.

Pelcowa SłLub - H. Pelcowa, Słownik Lubelszczyzny (referat na posiedzeniu Komisji Dialektologicznej Komitetu Językoznawstwa PAN, m. 1. 'źrenica oka').

Plet - M. Pleteršnik, Slovensko-nemški slovar, I-II, Ljubljana 1894-1895.

PS - Př́ruční slovník jazyka českého, I-VIII, Praha 1933-1957.

$\mathrm{RBE}$ - Речник на българския език, ред. К. Чола ков а, София 1977 i n.

Rembi szewska D. K., Słownik dialektu knyszyńskiego Czesława Kudzinowskiego, Łomża 2007.

Rězak F., Němsko-serbski słownik hornjołužiskeje rěče. Deutsch-wendisches encyklopädisches Wörterbuch der oberlausitzer Sprache, Bautzen 1920.

RHSJ - Rječnik hrvatskoga ili srpskoga jezika, I-XXIII, Zagreb 1880-1976.

RMJ - Речник на македонскиот јазик со српскохрватски толкуваға, ред. Б. Конески, I-III, Скопје 1961-1966.

RSBKE - Речник на съвременния български книжовен език, ред. Ст. Романски, I-III, София 1955-1959. 
RSHJ - Речник српскохрватског книжевног и народног језика, Београд 1959 i n.

RSHKJ - Речник српскохрватскога књижевног језика, Матица спрска-(Матица хрватска), I-VI, Нови Сад-(Загреб) 1967-1976.

Schuster-Š ewc H., Historisch-etymologisches Wörterbuch der ober- und niedersorbischen Sprache, I-V, Bautzen 1978-1996.

SDRJ - Словарь древнерусского языка (XI-XIV вв.), ред. Р. И. А в а н е сов, Москва 1988 i n.

SGPA - Słownik gwar polskich, oprac. przez Zakład Dialektologii Polskiej Instytutu Języka

Polskiego PAN w Krakowie pod kier. M. Kara sia, od t. II pod kier. J. Reichana, od t. VI pod kier. J. Okoniowej, Wrocław 1977 i n.

SGPK - J. Karłowicz, Słownik gwar polskich, I-VI, Kraków 1900-1911.

Siatkowski DCK - J. Siat kowski, Dialekt czeski okolic Kudowy, I-II, Wrocław 1962.

SJPD - Słownik języka polskiego, pod red. W. Doroszew skiego, I-XI, Warszawa 1958-1969.

Skok P., Etimologijski rječnik hrvatskoga ili srpskoga jezika, I-IV, Zagreb 1971-1974.

Sławski SE - F. Sław ski, Słownik etymologiczny języka polskiego, I-V, Kraków 1952-1982.

SłPogr - Слоўнік беларускіх гаворак паўночна-заходняй Беларусі і яе пагранічча у пяці тамах, рэд. Ю. Ф. Ма ц ке віч, Мінск 1979-1986.

Snoj M., Slovenski etimološki slovar, Ljubljana 1997.

Sobierajski Z., Atlas polskich gwar spiskich na terenie Polski i Czechostowacji, I-IV, Poznań 1966-1977.

SP - Słownik prasłowiański, oprac. Zespół Zakładu Słowianoznawstwa PAN, red. F. Sła wski, Wrocław 1974 i n.

SrezMat-И. И. Срезневск и й, Материалы для Словаря древнерусского языка, Санкт-Петербург 1893-1912.

SRJ XI-XVII - Словарь русского языка XI-XVII вв., ред. С. Г. Бархударов (Ф. П. Фи лин, Д. Н. Шмелев, Г. А. Богатова), Москва 1975 i n.

SRJ XVIII - Словарь русского языка XVIII века, ред. Ю. С. Сорокин (З. М. Пе трова), Ленинград (Санкт-Петербург) 1984 i n.

SRNG - Словарь русских народных говоров, составил (с II т. гл. ред.) Ф. П. Фи лин, Москва-Ленинград 1965 i n.

SSJ - Slovník slovenského jazyka, red. S. Pecia r, I-VI, Bratislava 1959-1968.

SSJČ - Slovník spisovného jazyka českého, I-IV, red. B. Hav ránek, Praha 1960-1971.

SSKJ - Slovar slovenskega knjižnega jezika, I-V, Ljubljana 1970-1991.

SSN - Slovník slovenských nárečí, red. I. Ripka, Bratislava 1994 i n.

SSRLJ - Словарь современного русского литературного языка, ред. Ф. П. Фи л и н, I-XVII, Москва-Ленинград 1950-1965.

SStp - Słownik staropolski, red. S. U rbańczyk, I-XI, Warszawa 1953-Kraków 2004.

SSUM - Словник староукраїнської мови XIV-XV cm., ред. Л. Л. Гумец ька, I-II, Київ 1977-1978.

Starosta M., Dolnoserbsko-nimski słownik. Niedersorbisch-deutsches Wörterbuch, Budyšyn/ Bautzen 1999.

SUM - Словник української мови, ред. І. К. Бі лоді д, I-XI, Київ 1970-1980. 
Słowiańskie nazwy ‘źrenicy’ w świetle materiałów gwarowych i źródeł historycznych 173

SUM XVI-XVII - Словник української мови XVI - першої половини XVII cm., ред. Д. Гр и н ч и ш и, Львів 1994 і n.

Sycht a B., Słownik gwar kaszubskich na tle kultury ludowej, I-VIII, Wrocław 1967-1976.

TRMJ - Толковен речник на македонскиот јазик, гл. ред. К. Конеск и, Скопје 2003 i. n.

TSBM - Тлумачальныслоўнікбеларускаймовы, падрэд.К.К. А т раховіча (К. Кра півы), I-V, Мінск 1977-1984.

Tymčenko - Є. Т и м чен ко, Матеріали до словника писемної та книжної української мови XV-XVIII cm., підготували до видання В. В. Німчук та Г. I. Лиса, I-II, Київ-Нью-Йорк 2002-2003.

Varbot Ž. Ž. - informacje ustne.

Vasmer ESRJ - М. Фасмер, Этимологический словарь русского языка, перевод с нем. и дополнения О. Н. Трубачев а, I-IV, Москва 1964-1973.

Zaręba A., Atlas językowy Śląska, I-VIII, Kraków 1969-1989, Warszawa 1996.

\section{Slavic Names of the 'Pupil' ('źrenica') in the Light of Dialect Materials and Historic Sources}

\section{(Summary)}

Despite a considerable mixture of names of "the pupil", their collateral use and not quite distinct borders of ranges of specified lexemes, it is possible to specify several express, albeit not quite well-defined, areals (map 1).

In Russia and in eastern regions of Belarus and Ukraine, the name ${ }^{*} z / / \operatorname{orčb}_{b}$ ( $\left./ />\mathrm{d}\right)$ dominates. In the areal of this name, it is possible to define the areal of a separate or collateral occurrence of names ${ }^{*} Z / / b r b k b$, more rarely ${ }^{\star} z / / \operatorname{irz} k z(Z>s, \check{z} ; / />v)$ southward and eastward from Moscow, names ${ }^{*}$ ględèlbce, ${ }^{*}$ ględélbca and ${ }^{*}$ ględélbcr in the vicinity of Pskov and Novgorod

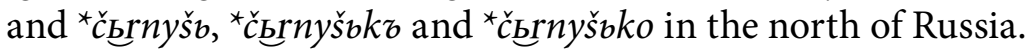

In Poland and in the Czech Republic, ${ }^{\star} G$ bpanonøka $(G B>\emptyset)$ occur, besides, ${ }^{\star} z$ brènica also occurs in Poland.

In Ukraine and in eastern Belarus, ${ }^{*}$ čelověčbkr dominates, while *čelověčbko is less numerous; in southern Bulgaria, Macedonia and in Slavic settlements on the territory of Greece and Turkey the forms ${ }^{*}{ }^{*} E L o V e \check{e} c$,

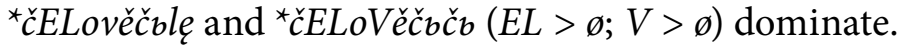

In Serbia and Croatia and somewhat in Slovenia and south-western Bulgaria, the name ${ }^{\star}$ zènica prevails. 
Map 2 (motivation map) shows most visibly two types: from the verbs meaning 'patrzeć' („to see”), which occur in the prevailing part of the Slavic territory, and from the words meaning persons and things that are reflected in „the pupil” ('źrenica') and are represented in western Ukraine and western Belarus, on the prevailing territory of Poland, in the Czech Republic and Moravia, in the south-eastern part of Slovakia and also in Macedonia, southern Bulgaria and in Slavic settlements on the territory of Greece and Turkey. Both of these types were registered as a certain mixed type, in particular, in eastern Ukraine and eastern Belarus.

The names that are motivated by the black color of "the pupil" ('źrenica') are found mainly in northern Russian and in southern Macedonian dialects; less frequently they appear in the territory of Austria and in Lużyce. Motivation types from the names meaning round, shining and luminous objects, and from the names that are diminutive names of the eye are very sporadic and occur in great dispersion. 